\title{
Challenges and opportunities for
} increased policy recognition of family and child health and wellbeing within the USA and internationally

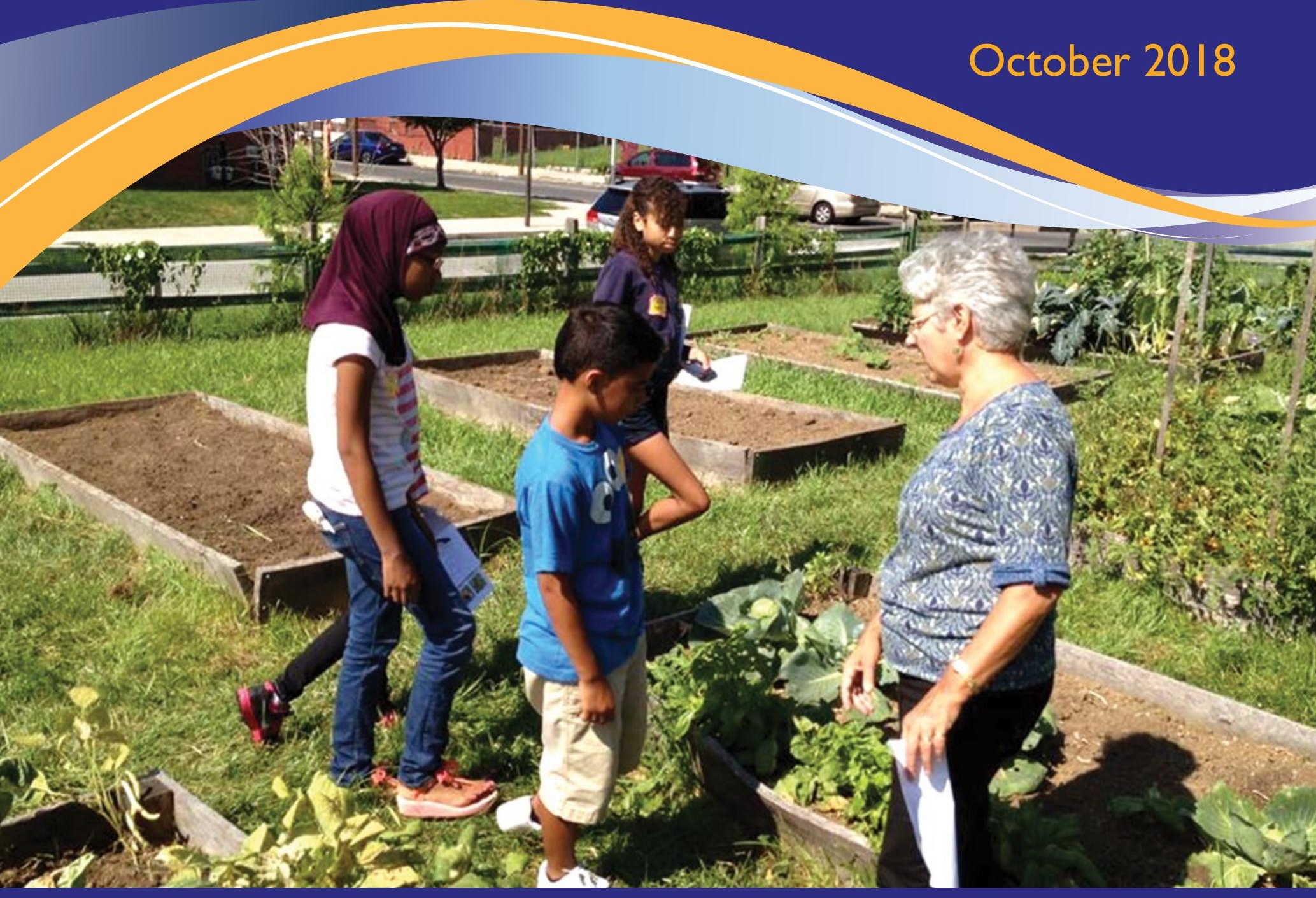

Pamela Abbott, Lucia D'Ambruoso, University of Aberdeen with

Training and Research Support Centre

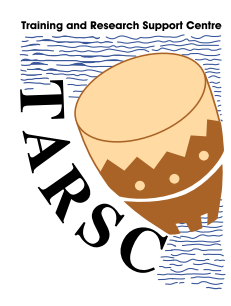

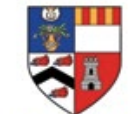

UNIVERSITY OF ABERDEEN
Programme led by TARSC With support from a grant awarded by the Robert Wood Johnson Foundation Global Ideas Fund at CAF America 


\section{Table of contents}

Executive summary 2

1. Introduction 4

2. Methods 4

3. Findings 5

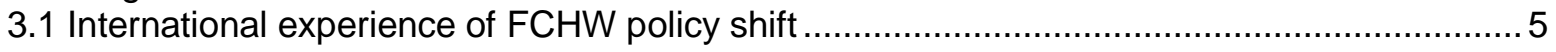

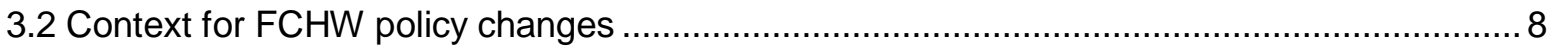

3.3 Drivers of increased policy recognition of FCHW ............................................................ 10

4. Trends in FCHW policy in the USA 13

4.1 Measuring progress in promoting FCHW: How is the USA doing? ..................................13

4.2 Levels of and contexts for policy recognition of FCHW in the USA ..................................15

4.3 Areas of increased FCHW policy recognition in the USA .............................................18

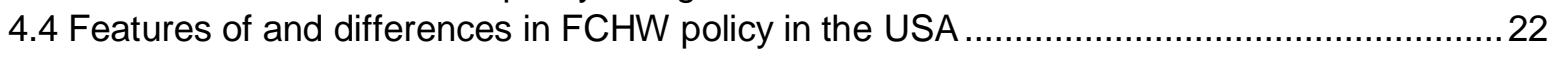

5. Comparing FCHW policy in the USA and in other countries 24

6. Challenges and opportunities in the USA 26

7. Discussion 30

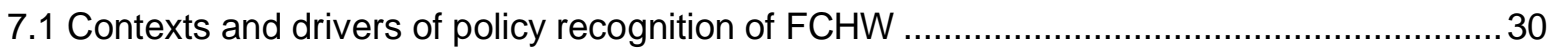

7.2 Implications for country selection for the case studies ............................................. 31

References $\quad 33$

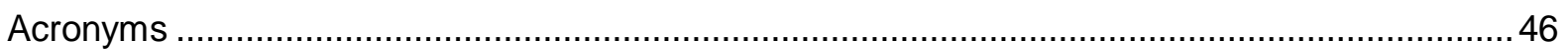

$\begin{array}{ll}\text { Appendix } 1 & 47\end{array}$

Cite as: Abbott P, D'Ambruoso $L$ (2018) Challenges and opportunities for increased policy recognition of family and child health and wellbeing within the USA and internationally, University of Aberdeen and Training and Research Support Centre.

Acknowledgements: With thanks to Dr Rene Loewenson, TARSC, for inputs on the framework for the paper, scientific inputs and materials and internal peer review and technical edit. We acknowledge further the helpful comments from Erin Hagan, Evidence for Action, and from Victoria Brown and Claire Gibbon, RWJF, as external US peer reviewers.

The project on 'Fostering policy support for child and family wellbeing - Learning from international experience', co-ordinated by the Training and Research Support Centre and in co-operation with University of Aberdeen, aims to gather evidence and build learning on how policy norms and recognition have shifted in low-, middle- and high-income countries and internationally towards support of FCHW, to draw transferable learning for the US context. Support for this research was provided by the Robert Wood Johnson Foundation Global Ideas Fund at CAF America. The views expressed here do not necessarily reflect the views of CAF America, the Robert Wood Johnson Foundation, Training and Research Support Centre or the Court of the University of Aberdeen. 


\section{Executive summary}

Advocating for greater priority for family and child health and wellbeing policy at the system level in the United States raises the question: How have policy norms and recognition for policy and systems shifted in other countries and internationally to support family and child health and wellbeing (FCHW)? What transferable learning is there for the USA? The project aims to generate evidence to respond to this question. It seeks to explore learning from other countries globally and from global actors as to what conditions, actors, processes and factors have contributed to a change in policy norms and recognition to support FCHW, and what transferable learning there may be for USA at federal, state or local levels.

Following the development of an analytic framework, this paper reports on challenges and opportunities for increased policy recognition of FCHW within the USA at national (federal) and state levels and in other low-, middle- and high-income countries. It reviews how FCHW is prioritised and how contextual factors and understandings of FCHW vary across settings and countries. It discusses potential learning for the USA from countries that have implemented policies and programmes to promote FCHW. This review adds to and will be triangulated with evidence from separate papers in the project to identify countries, areas of focus and key informants for case studies in policy recognition of FCHW. The report is structured as follows:

- In Section 2, we describe our methods.

- In Section 3, we present evidence on increased policy recognition of FCHW, the context and drivers for it internationally and in the USA.

- In Sections 4 to 6, we present evidence on trends in FCHW policy recognition in the USA; on features and differences in FCHW policy in the USA relative to other countries; and on opportunities, challenges for FCHW policy recognition in the USA;

- In Section 7, we discuss the findings and their implications for the countries to consider in the follow-up triangulation of evidence for selection of case study countries.

We reviewed published literature to identify and synthesise papers and reports related to FCHW policy recognition, shifts, opportunities and challenges. We used terms derived from the analytical framework to perform systematic searches of bibliographic databases and online portals for published material 2000-2018. Articles were selected using inclusion criteria, and data extraction and narrative synthesis of retrieved articles were performed. According to this strategy, 279 reports and papers were included.

The evidence revealed shifts towards FCHW recognition across low-, middle- and high-income countries. These included: policies to raise family incomes; services for all children and their families such as Early Childhood Education and Care (ECEC); policies that better enable parents to care for their children such as maternity and parental leave; community services to support vulnerable families; and policies to promote the wellbeing of children in care. The evidence suggested that areas of, and contexts for, policy recognition are characterised by the following:

- Values, beliefs, norms and ideological commitments to inclusion and collective responsibility for FCHW or a religious/philosophical commitment to promoting wellbeing;

- Socio-demographic changes: declines in family size, demographic transition, an increase in lone parent families and an increase in dual earner families;

- Major social tipping points (crises and political transitions);

- Ratification and domestication of the Convention on the Rights of the Child (CRC) giving governments and families responsibility for protecting and promoting wellbeing of children;

- International institutions and development partners promoting rights and democracy through an emphasis on good governance, maternal and child health, and quality education for all;

- International and regional organisations that promote FCHW;

- Extra incentives for low- and middle-income countries through aid conditionality.

While the USA has the highest gross domestic product (GDP) of OECD countries, it is among the most unequal and does comparatively poorly on spending and wellbeing outcomes for children. The USA also compares poorly on family-friendly policies such as parental leave, flexible 
working, and childcare. Policy remains focused on protecting children from abuse and neglect and ending dependency on benefits rather than reducing child poverty or helping all families to raise healthy children. The USA has not domesticated the CRC, and there was no evidence of international agencies working to promote FCHW in the USA. In terms of social and cultural norms and values, responsibility for child wellbeing is seen as the responsibility of parents and the family as a private sphere, with the state only intervening when things go wrong. A strong lobby for traditional family values is documented to have blocked more progressive legislation to promote FCHW. We found evidence, however, that Americans see investing in children as important and are demanding that government addresses these concerns. The federal system of government is thought to make it difficult to create coherent policies for child wellbeing with fragmentation disrupting access to services.

Areas of increased policy recognition in the USA relate to: increasing the incomes of poor families; reducing inequalities in educational outcomes; extending health insurance to poor children; improving access to medical care; safeguarding vulnerable children; innovations in child welfare service delivery; and reforms to child welfare funding. To the extent that there are shifts towards promoting child wellbeing, it was mainly for children at risk of being taken into care or those already in the welfare system. NGOs and child advocacy groups were identified as advocating for FCHW. Several promising initiatives were identified of federal, state and local efforts to promote child wellbeing in the welfare system and community-based support initiatives. A key lesson reported in these initiatives was the importance of community strengthening addressing the needs of children and parents.

The evidence suggests opportunities for increased policy recognition in FCHW in the US in:

- Making the economic case for collective investment in FCHW, with a focus on children;

- Acting on American public opinion showing support for children's equal opportunities and willingness to spend more money on them, especially for health, ECEC and social protection to support the standard of living of disadvantaged or vulnerable groups;

- Taking advantage of policy windows arising from a federal system whereby progressive states can introduce policies to promote FCHW and technical options for policy innovation;

- Expanding initiatives for paid parental leave and income support;

- Strengthening community services and advocacy for vulnerable children and those at risk;

- Improved co-ordination between departments and agencies at federal level;

- Responding to everyday concerns around basic needs for households and value for money concerns for funders and providers in demonstrating effective, relevant and equitable options for use of public expenditures for FCHW.

Countries and experiences that would be of interest for further focus include ones that have shown positive trends in FCHW policy relevant for the USA and where there may be opportunities for policy recognition in the USA that draw on positive changes internationally, in:

- Reducing child poverty and social (ethnic, racial) inequalities and integration of migrant children;

- Introduction of social protection and safety nets for children and legal entitlements to maternity and parental leave and flexible working for parents;

- Entitlement of at least one year of free quality ECEC and measures for improved educational outcomes for all children;

- Preventive policies and community-based programmes to reduce the risk of children being taken into care and to improve options for them to be reunited with their families;

- Improved health promotive, preventive and care coverage, including for adolescents;

- Co-ordination of the delivery of FCHW policies, services and programmes at national, state and local levels, with incentives for and use of local programmes for learning on innovation;

- Strengthened community information, systems, networks and advocacy;

- Investment in good quality data, including subjective and disaggregated data used by affected groups, technical and political actors for advocacy, planning, monitoring and review;

- Child impact statements assessing the effects of legislation, policy and services on children to assist decision-making positive for children. 


\section{Introduction}

Advocating for greater priority to be given to family and child health and wellbeing policy at the system level in the USA raises the question: How have policy norms and recognition for policy and systems shifted in other countries and internationally to support family and child health and wellbeing (FCHW)? What transferable learning is there for the USA? The project 'Fostering policy support for child and family wellbeing - learning from international experience', coordinated by the Training and Research Support Centre (TARSC), working with the University of Aberdeen, aims to generate evidence to respond to this question. It seeks to explore the learning from other countries globally and from global actors as to what conditions, actors, processes and factors have contributed to a change in policy norms and recognition to support FCHW, and what transferable learning there may be for USA at federal, state or local levels.

Following the development of a thematic and analytic framework for the work (Loewenson and Masotya, 2018), this paper reports on challenges and opportunities for increased policy recognition of FCHW in the USA at national (federal) and state levels and in other low-, middleand high-income countries. It reviews how FCHW is prioritised. It examines how contextual factors and the understanding of FCHW vary across a range of settings within and across countries and are shaped by gender, class, ethnicity and age (Ben-Arieh et al., 2014; Sandin, 2014; Weisner, 2014). It discusses the potential learning for the USA from countries that have implemented policies and programmes to promote $\mathrm{FCHW}$, while recognising that structural, socioeconomic, political economy, cultural contexts and parenting styles influence the extent to which there has been increased recognition of FCHW, the types of policies developed and how they are delivered (Pecora, McAuley and Rose, 2006; Ben-Arieh et al., 2014; Weisner, 2014). This review will be triangulated with evidence from separate papers produced in the project (a second review paper on country experiences and an analysis of country data on investment in FCHW) to identify countries, areas of focus and key informants for case studies of experiences, processes, drivers of and factors affecting positive changes in policy recognition of FCHW.

This report is structured as follows:

- In Section 2, we describe our methods.

- In Section 3, we present evidence on increased policy recognition of FCHW, the context and drivers for it internationally and in the USA.

- In Sections 4 to 6, we present evidence on trends in FCHW policy recognition in the USA; on features and differences in FCHW policy in the USA relative to other countries; and on opportunities, challenges for FCHW policy recognition in the USA.

- In Section 7, we discuss the findings and their implications for the countries to consider in the follow-up triangulation of evidence for selection of the case study countries.

\section{Methods}

The search strategy was iterative and proceeded through repeated rounds of searching, reflection and further searching. Searches were conducted using search terms identified in the analytic framework (Loewenson and Masotya, 2018) to identify relevant documented evidence on FCHW laws, strategies, policies, advocacy, services, promotion and rights. First, we included papers post-2000 in English, French and Spanish using six major online bibliographic databases (Table 1). The following search terms were employed: "child health", "child wellbeing", "child welfare", "child poverty", "child development", "child protection", "child health promotion", "child rights", "family health", "family wellbeing", "family welfare", "family health promotion", "child law", "family law", "child policy", "family policy" "child strategy" "family strategy" "child agency" and "family agency". Terms were combined using Boolean operators "AND/OR" in combinations according to the online portal. Second, we conducted searches in Google and on the portals of key organisations post-2000, including the United Nations Children's Fund (UNICEF), UNICEF Innocenti Research Centre, and Organisation for Economic Co-operation and Development (OECD) and non-governmental organisations (NGOs) in the USA identified as promoting FCHW. Searches were also conducted by region - e.g. Africa, Latin America, Europe, USA and Asia. We 
also explored the USA at federal and state levels post-2000. Third, we did targeted searches for citations from key articles to find additional information. TARSC provided additional papers from its own analyses for other products and by peer reviewers.

\section{Inclusion criteria}

Titles and abstracts were reviewed to select papers and reports that related to FCHW policy recognition, policy opportunity, policy challenges and policy change. A selective review was then performed identifying for inclusion full texts that provided some form of evidence of a policy shift. Following this strategy, 279 reports, papers and websites were included.

Table 1: Summary of search findings

\begin{tabular}{|c|c|c|c|}
\hline \multirow[b]{2}{*}{ Source } & \multicolumn{2}{|c|}{ \# papers selected } & \multirow[b]{2}{*}{ Comments } \\
\hline & From searches & After review & \\
\hline 1. Medline & 1060 & 30 & English \\
\hline 2. Embase & 1497 & 49 & English \\
\hline 3. PsychINFO & 823 & 53 & English \\
\hline 4. SSCI (WoS) & 960 & 35 & English \\
\hline 5. Scielo & 693 & 70 & English, French and Spanish \\
\hline 6. Ajol & 39 & 11 & English, French and Spanish \\
\hline $1^{\text {st }}$ selection $(1-6)$ & - & 235 & Removal of 13 duplicates \\
\hline $2^{\text {nd }}$ selection (1-6) & - & 27 & \\
\hline Google + other & 303 & 262 & \\
\hline Total & - & 279 & \\
\hline
\end{tabular}

Data extraction and analysis

We used narrative synthesis to summarise and explain the findings and draw conclusions. We drew on a definition proposed by Popay et al: "the defining characteristic is that it adopts a textual approach to the process of synthesis to 'tell the story' of the findings from the included studies" (Popay et al., 2006). Retrieved papers and reports were reviewed and key information abstracted relevant to our questions. From the data extraction, a textual account of: instances of increased recognition for FCHW; the drivers and contexts of policy shifts and recognition; the features and differences of policy shifts and recognition; and opportunities and challenges for increased policy recognition were developed. The focus, framing and text were revised following peer review of the findings by TARSC and discussion at team meetings.

\section{Limitations}

We note two main limitations. We acknowledge that some relevant literature may have been excluded. Although we retrieved articles written in French and Spanish, we carried out searches using English search terms only. This meant that some regions and countries may be underrepresented. Further, we note that very recent policy shifts may not yet have found their way into the literature. There was limited discussion in the literature reviewed of social/voice drivers of policy change, so our analysis may underestimate their importance and of how policy options are translated into polices. However, we judge that these limitations are not so significant as to mean that the paper does not still provide useful evidence of policy drivers and opportunities in the USA and internationally relevant to FCHW.

\section{Findings}

\subsection{International experience of FCHW policy shift}

In this section we describe examples of increased policy recognition for FCHW internationally and discuss the contexts in which these occurred. A further paper will outline specific experiences in selected countries where there has been a change in policy recognition for FCHW post-2000. The case studies in selected countries to be implemented in 2019 in the project aim to provide further detail on the conditions, actors, processes and factors that have contributed to a change in policy norms and recognition to support FCHW in the selected countries.. 
Recognition of FCHW in policy has been marked by several specific shifts:

- From welfare (child saving/protection of children at risk) to the wellbeing of all children, reducing inequalities and ensuring no child is left behind (Rose and Rowlands, 2010; Coles et al., 2016).

- From protecting children against negative outcomes to promoting individual and collective wellbeing and ensuring all children have the opportunity to develop the capabilities to make real choices and live in ways that they value (Gilbert, Parton and Skivenes, 2011; Ben-Arieh, 2014; Dang, 2014).

- From taking vulnerable children into care to preventive services for families in the community (Hatton, no date; Waldfogel, 2009; Institute of Public Care, 2010; Gilbert, Parton and Skivenes, 2011).

- From well-becoming to wellbeing, taking a life course perspective recognising early years experiences for health, education and employment outcomes later in life (Carpenter, 2007; Ben-Arieh, 2010b; Department of Children and Youth Affairs, 2016).

- From seeing children as dependent to seeing them as able to report on their own wellbeing and contribute to decisions about their lives (The Children's Society, 2012; Ben-Arieh et al., 2014; Sandin, 2014; Bradshaw and Rees, 2017).

- From families seen as being the problem to families seen as having problems and parents seen as needing specific information, support and skills to enable them to promote their children's and their own wellbeing (Daly et al., 2007).

- From FCHW seen mainly as the responsibility of individual families to being seen as a collective responsibility, recognising the need to tackle social and economic structures that are major causes of inequality in wellbeing (Prilleltensky and Nelson, 2000; Jenson, 2004; Banati and Alexander, 2012; Council of Australian Governments, 2014).

- Towards recognising that investment in services to promote FCHW brings both economic return to society and social benefits (Danziger and Waldfogel, 2000; Schaefer, Gates and Kiernan, 2010; Trostel, 2013; Bishop-Josef et al., 2014; Daly et al., 2015).

The shifts include providing universal income-support programmes for families with children, universal health services, affordable childcare for pre-school and school-aged children, public education, guaranteed support after marital breakdown, job training and assistance, a legal entitlement to paid family leave and social (affordable) housing (Baker, 2006). There has also been a shift from social protection, which can be defined as a sub-set of public actions that help address risk, vulnerability and chronic poverty, to promoting the wellbeing of children in care (Parton and Skivenes, 2011). Shifts occurred over relatively short periods and more gradually; however, all elements were identified as central to a shift towards a more holistic policy recognition of FCHW.

Increased policy recognition in countries internationally

The evidence shows shifts towards recognition of FCHW across low-, middle- and high-income countries (Gabel, 2010; UNICEF, 2007; Seymoor, 2009; Lundy et al., 2012; Davidson, 2014; Daly et al., 2015). These included: policies to raise family incomes; services for all children and their families such as Early Childhood Education and Care (ECEC); policies that better enable parents to care for their children such as maternity and parental leave; community services to support vulnerable families; and policies to promote the wellbeing of children in care. All OECD countries, except for the USA, have legal provisions for paid parental leave. Almost all entitle mothers to at least 14 weeks paid maternity leave in line with the International Labour Office (ILO) recommendation. Ten countries give mothers an entitlement to at least one year's leave and 31 countries give fathers an entitlement to paid paternity leave (OECD, 2017c). Again, with the exception of the USA, all OECD countries entitle children to at least one year of universally available ECEC (OECD, 2017d). The OECD average is for $80 \%$ of four year olds to be in ECEC, rising to well over $90 \%$ in some countries (Gambaro, Stewart and Waldfogel, 2015b). Investment in pre-school education is the most strongly associated with promoting child wellbeing and OECD countries that invest in FCHW have lower poverty rates (Richardson, 2014).

Strengthened family support initiatives were found in western, central and eastern Europe, the Commonwealth of Independent States, Latin America, Australia and Canada and some parts of eastern and southern Africa and Asia. A number of countries, including Belarus, Croatia, England, Romania and Turkey, introduced support for all parents (Daly et al., 2015). Fifty countries, including 
high- and middle-income countries, provide universal free health care (World Atlas, no date), while Columbia, India, Korea, Mexico and Turkey are amongst those transitioning to universal health coverage (OECD, no date).

This section provides examples of these shifts in selected countries, to illustrate them in practice. Separate review work in the project is exploring information on shifts and drivers in specific countries identified as having evidence of increased FCHW policy recognition.

Among high-income countries, the United Kingdom (UK) made a rapid shift from child welfare to child wellbeing, following the 1997 election of a Labour party led government committed to putting children first (Chief Secretary to the Treasury, 2003; Aldgate, 2010; Rose and Rowlands, 2010; Waldfogel, 2010; Bogenschneider, 2011; Lundy et al., 2012; Daly, 2015; Coles et al., 2016). State policies included: making work pay by introducing a minimum wage and Working Tax Credits; universal child-income support; universal entitlement to ECEC; support for young people in low income households to stay in education; and improved paid parental leave (Lister, 2008; Waldfogel, 2010). UNICEF and NGOs such as the Joseph Rowntree Foundation and the Save the Children Fund played important roles bridging the policy and politics streams and commissioning research to monitor the impact of the new policies (Lister, 2008). Tony Giddens, a public intellectual, advised Prime Minister Tony Blair and Gordon Brown, the Chancellor of the Exchequer, a strong advocate for FCHW policies (Lister, 2008; Rose and Rowlands, 2010; Waldfogel, 2010; Daly, 2015). The reforms resulted in an increase in ECEC and a decline in child poverty attributable to government policy (Waldfogel, 2010; Gambaro, Stewart and Waldfogel, 2015a). The UK moved from ninth ranked OECD country for spending on family benefits in 2000 to first in 2013 (OECD, 2017b).

Canada, another high-income country, has shifted from a paradigm in which parents were seen as responsible for their children's welfare to one where responsibility for promoting wellbeing of all children is shared by the family and the state (Jenson, 2004; Davidson, 2014). The shift can be attributed not only to new social and economic risks from demographic transition, but also to a social learning network of advocates and experts from civil society and the state effectively linking the policy and politics streams.

Following the 1994 genocide against the Tutsis, Rwanda, a low-income and aid-dependent country, made a commitment to improve the lives of all citizens including children. Since 2000 it has put in place a comprehensive legal and policy framework to promote FCHW, including ECEC, 12-year feefree education, community health services and insurance and policies to reduce poverty. UNICEF, INGOs and development partners played important roles as policy entrepreneurs bridging the problems, policy and politics streams. They both advocated for FCHW and supported government in developing and implementing policies. Although budgetary constraints make implementation challenging, Rwanda was one of the few countries that achieved most of its Millennium Development Goal (MDG) targets (Abbott and Sapsford, 2012; Abbott, 2013; Abbott, Sapsford and Binagwaho, 2017).

In Chile, a middle-income country, a democratically elected government in 1988 following 17 years of dictatorship, introduced policies aimed at socially inclusive economic growth, including narrowing socioeconomic inequalities and improving health outcomes for all (Frenz, 2007). Chile Solidario 2002 is a conditional cash transfer social protection system that focuses on families in extreme poverty. It requires eligible families to participate in family support to get income support and preferential access to government social programmes (Frenz, 2007; Centre for Public Impact, 2016; Torres et al., 2017). Chile Crece Contigo 2007 provides services to support early child development for all from birth to four years including ECEC, parental leave, health surveillance and targeted support for children in the poorest $40 \%$ of homes (Frenz, 2007).

Bhutan is a lower-middle income country that has made progress in setting a legal and policy framework to promote child wellbeing (UNICEF, no date a; Camilletti, 2018). Like Rwanda it invests heavily in the social sectors, was one of the few countries globally to achieve most MDGs and has UNICEF and INGOs that advocate for children and support the government in implementing policy. Bhutan is committed to measuring development by improvement in the wellbeing of its population 
and has introduced a wellbeing agenda into schools that has improved students' academic attainment and wellbeing (Adler, 2009, 2016; Adler and Seligman, 2016; Seligman and Adler, 2018).

\subsection{Context for FCHW policy changes}

The contextual factors for policy shifts vary between high-, middle-, and low-income countries and between countries within income groups.

\section{The global and international context}

The passing of the UN Convention on the Rights of the Child (CRC) in 1989 was a clear paradigm shift in giving children the right to being well (wellbeing), transcending mere access to social services; and in giving governments and families responsibility for protecting and promoting child wellbeing (Articles 4, 5, 6, 7, 18, 26, 27, 28) (Gabel, 2010; Aldgate, 2010; BenArieh, 2010a; Bruyere and Garbarino, 2010; Kamerman, Phipps and Ben-Arieh, 2010; Sandin, 2014; Ben-Arieh et al., 2014; Daly et al., 2015; Mag, 2015; Dejene et al., 2016). The CRC is informed by an ecological perspective. It sets a multidimensional approach to child wellbeing as dependent on the quality of their material, social and cultural environments, as well as care and nurturing received in the family (Articles 4, 5, 24,26, 27) (Ben-Arieh, 2010b). It marked a shift from the family as a collective entity governed by parental authority to an environment for nurturing children and protecting their rights (Gabel, 2010; Ben-Arieh, 2010a; Sandin, 2014; Daly et al., 2015). While parents are seen as having the primary responsibility for this, the state has a duty to support them and to minimise risk (Articles 4, 5, 9, 18, 26, 27). It provides a normative child-focused framework for children's wellbeing, based on the concept of "in the best interest of the child" (Article 3), irrespective of race, gender, socioeconomic or immigrant status (Articles 2, $20,22,23,30$ ). The CRC provides for physical and intellectual integrity (Articles 34, 35, 36,37), for all children to be given the best start possible in life (Articles 6, 28, 29), for their voices to be heard and for them to be consulted about their lives and what is important for them (Articles 12, 13) (Ben-Arieh, 2010a, 2010b; Sandin, 2014).

In the 20 years preceding UN approval of the CRC, INGOs had advocated for child rights in lowand middle-income countries (Gabel, 2010). They were motivated by high levels of child, infant and maternal mortality and poor access to housing, safe water and sanitation; high levels of poverty and social inequality; and food insecurity and child malnutrition (Nanji, Nanji and Manji, 1991; Loewenson, 1993; Heward and Bunware, 1999). Advocacy was also a response to low school attendance, high dropout, low primary school completion, child labour and girls forced into early marriage and child bearing. In response to INGOs advocacy, the UN declared 1979 as the International Year of the Child (Gabel, no date). During the year, child rights were adopted as the global framework for promoting child wellbeing and agreement reached that a new Convention replace the 1959 non-binding Declaration of the Rights of the Child. The CRC, passed unanimously by the UN General Assembly, has become the most ratified UN treaty. Significantly only one UN member state, the USA, has not ratified it (Mehta, 2015).

Various regional and global processes have since added to the CRC. In Africa, the 1990 African Charter on the Rights and Welfare of the Child (ACRWC) has levered increased policy recognition of FCHW (Mekonen, 2009). Both the CRC and the ACRWC shifted from the child being seen only as a 'potential' adult (i.e. less than fully human) to being seen as having claim to a range of rights, with the state and families responsible for promoting child wellbeing (Cusworth and Bradshaw, 2007; Camfield, Streuli and Woodhead, 2008). They give children the right to enjoy childhood and to be prepared for adult life.

The UN Millennium Summit in 2000 agreed a global partnership for development, setting MDG targets for 2015 (Daly et al., 2007; Lundy et al., 2012; Sandin, 2014; Dejene et al., 2016). Like the Sustainable Development Goals (SDGs), which have replaced them, they are informed by a vision of the world where all children thrive and achieve their full potential. The SDGs place greater emphasis on reducing inequalities (Bhardwaj, Sambu and Jamieson, 2017). Within these UN-led efforts, UNICEF plays a key role in promoting child wellbeing with INGOs and a range of international and regional institutions, including the World Bank, the OECD, the African Union $(A U)$, the Doha International Family Institute (DIFI) and the European Commission (EC) (Daly et al., 2015). The CRC and MDGs have been used as soft tool for applying diplomatic pressure on 
governments (Gabel, 2010). The requirement of periodic reports on CRC implementation and publication of reports and league tables on the MDGs and in promoting child wellbeing have proved to be powerful incentives for shifting policies in high-, middle- and low- income countries (Tisdall, 2015; Dejene et al., 2016). OECD countries have also made aid conditional on making progress in democracy and promoting human rights, including children's and women's rights (Crawford, 1997; Abrahamsen, 2000).

\section{National contexts}

Demographic and social trends have been important contexts for policy shifts towards FCHW (Lamb, 2009; Kamerman, 2010; Settersten, Mcclelland and Miao, 2014; Daly et al., 2015). Many high-, middle- and low-income countries have persistently high levels of child poverty and social inequalities in child wellbeing by race, gender, migration status and socioeconomic group.

Middle- and low-income countries are in demographic transition, with declining birth rates and a bulge in working age populations. To respond, countries need to create employment opportunities for young people coming into the labour market. This implies educating children to prepare them for employment, increasing the time that young people are dependent on their families (Ssewamala, 2015). High-income countries have experienced declining fertility to below replacement levels, ageing populations, increases in lone parent families, declines in support from extended families, rises in dual working couples and increases in antisocial and deviant behaviour by young people. These have driven both need and demand for policies to support families in caring for and nurturing their children (Baker, 2006; Waldfogel, 2006; Kamerman, 2010; Sandin, 2014; Daly et al., 2015). In response, many high-income countries see welfare spending as an investment in future economic growth and investment in ECEC and education as a collective good benefitting children and the economy (Baker, 2006; Lister, 2008; Sandin, 2014).

Within countries, dominant beliefs and ideologies together with the history of public intervention by states influence the specific policies introduced (Daly et al., 2015; Huntington and Scott, 2015). The state is generally the most significant promoter and provider of services for children and families. In high-income countries, two broad FCHW welfare regimes are identified: a residual model found for example in the USA, UK, Canada and Australia that emphasises parents' rights and makes a distinction between needs and risk, while a universal needs-based model as found in the Nordic countries and continental Europe has generally stronger, sustained support for FCHW (Coles et al., 2016).

The shift in many high-income countries to an 'investment state model' views FCHW as an investment in future workers and as enabling families to manage risks such as marital breakdown and the decommodification of labour (Lister, 2003; Starke, Obinger and Castles, 2008). Low-income countries have equally made progress in FCHW, such as Rwanda described earlier, where government investment in population wellbeing is seen as a strategy for nation building (Chambers and Booth, 2012). In contrast, poverty and resource limitations, authoritarian rule, conflict and instability, poor governance and accountability, and corruption have been identified in some countries to lead to a gap between policy and implementation (Mulinge, 2002; Dejene et al., 2016).

Conservative pro-family values can be a strong barrier to the introduction of policies to promote FCHW (Palley and Shdaimah, 2014; Dejene et al., 2016). In the USA, the Personal Responsibilities and Work Opportunities Act 1996 was observed to be more concerned with moving parents from welfare to work and encouraging marriage than the wellbeing of children and their families (Waldfogel et al., 2001; Waldfogel, 2006). Sociocultural norms and values relating to ideas of what the family is, of the appropriate role of parents, and acceptable child-rearing practices vary widely across countries, and strongly influence what FCHW policies are introduced, how they operate and their chances of success (Daly et al., 2015). Literature from middle- and low-income countries suggests that parenting support generally comes from wider kin groups and the community than the state (Daly et al., 2015). In resource-constrained countries family and community networks can be drawn upon to provide services, such as the support provided by volunteer community health workers to mothers and children in Rwanda (Abbott, Sapsford and Binagwaho, 2017), and paraprofessionals implementing primary healthcare improving child and family health in South Africa 
and Jamaica (Daly et al., 2015). Contemporary national and global tensions between populism and multiculturalism, and liberal versus conservative/isolationist values should also be noted.

A federal system of government, as for example in the USA, Germany and Belgium, can make consistent national implementation of FCHW policies problematic, as laws policies, practices and investment may vary at devolved levels (Curran, Houshyar and Lesley, 2012; Lundy et al., 2012). A change of government can result in a shift towards policies to promote FCHW as happened in the UK in 1997, in Australia in 2007 and in Switzerland in the late 1990s, where labour or liberal governments replaced conservative ones (Kuebler, 2007). Conversely, the election of the Coalition government in the UK in 2010 followed by a Conservative one in 2015 led to a reversal of some policies introduced by the previous Labour government. Documented evidence also indicated that NGOs advocating for child wellbeing and key advocates for children in parliament and the government can be important in a shift to FCHW policies (Lundy et al., 2012; Daly et al., 2015). The evidence further indicates that crises may be tipping points, with governments coming to power post crisis promoting FCHW, as described earlier in Rwanda and Chile, or in South Africa after the ending of apartheid in 1994.

\subsection{Drivers of increased policy recognition of FCHW}

In this section we use the project's analytical framework for retrospective analysis of drivers of the areas of increased FCHW policy recognition discussed in Section 3.1 (Loewenson and Masotya, 2018, 27). The framework, Appendix Figure A1, identifies seven broad questions that inform the analysis of policy shifts. Sections 3.1 and 3.2 discuss the first three of these, viz: the nature of, evidence of and context for changes in the policy priority given to FCHW. This section examines the three streams of policy drivers identified in the framework paper:

a. How problems/issues were framed in terms of the evidence on issues, raised by whom, and in what processes;

b. The policy options and content as developed by various actors and implementers;

c. The political engagement and actors informing and making decisions on policy shifts.

Policy entrepreneurs bridge and broker links between these streams and may support how they come together to tap windows of opportunity that provide openings for increased recognition and shifts in policies for FCHW.

The problem/issues stream contains the broad problems and conditions facing societies. Some of these become identified as issues requiring public and policy attention, the actors that are affected by and raise issues and the processes where this takes place, such as social movements, civil society, the media, researchers, information system managers and so on.

Many countries at all income levels have seen investing in FCHW as making good economic sense as a result of demographic factors and due to concerns about the negative impact that poverty and inequalities have on early development (Daly et al., 2015; Dejene et al., 2016). A range of problems and issues have been raised for public and policy attention including how to: ensure that policy is in the best interests of children; ensure that policies reduce poverty and inequality; break cycles of deprivation; and ensure babies survive and flourish so that every child has the best possible start in life. In high- and middle-income countries, increasing numbers of mothers have paid employment. With rising numbers of single parents and mothers, concerns have been raised about how best to ensure the wellbeing of children and how to enable women to combine work and care (Waterhouse, Hill and Hinde, no date; Baxter et al., 2007; Daly, 2015). Issues have been raised on how to ensure children have happy and productive childhoods and be prepared for adult life, and for children and families to have a voice in policy making and resource allocation (Lansdown, 2011; Ben-Arieh, 2014; Bradshaw, 2015). There have been pressures to push a focus on children up the policy agenda, to hold governments accountable on what they do for FCHW, and to effectively measure how children and their families are doing.

This has raised a range of specific issues including: the availability, cost and quality of ECEC; the benefit systems and cash transfers supporting low income (and low paid in work) families; and the rights of and services for specific vulnerable groups such as migrant children, children with harmful drug and alcohol use, orphans and children in institutional care. Attention has also been 
drawn to environments creating vulnerability in children, such as from internet and social media; urban diets and inactivity; violence and sexual abuse or unsafe neighbourhoods (Frenz, 2007; Gilbert, Parton and Skivenes, 2011; Gambaro, Stewart and Waldfogel, 2015b).

The social indicators 'movement' has played an important role in highlighting these problems, and in measuring and holding governments accountable for progress. This movement reflects a response to demands by international organisations and governments for objective and subjective indicators to measure the relative impact of policies on people, including children (Ben-Arieh, 2010b). With increased measurement of children's health and wellbeing, there has also been greater recognition of the role of subjective data, asking children how they feel about relationships with their families and people in their community, their education and life in general (Ben-Arieh, 2010a; Bradshaw et al., 2010; Burton and Phipps, 2010; The Children's Society, 2012; Ben-Arieh et al., 2014; Dinisman and Ben-Arieh, 2016). This enables an understanding of what is important to children and how to improve children's experience of childhood (Aber et al., 2010; Burton and Phipps, 2010; Bradshaw and Rees, 2017). There is also evidence that wellbeing measured by objective indicators is related to subjective assessments of wellbeing (Lippman, 2005; Land, Lamb and Zheng, 2009; Richardson, 2014; Bradshaw, 2015).

The development of indicators and the measurement and public reporting of progress in implementing policies to promote FCHW was commonly reported to be a powerful incentive driving policy recognition and change and investment. Measures of child wellbeing have provided information for policy makers, civil society, parents and children themselves, and credible evidence has influenced policy makers in decisions to support FCHW (Ben-Arieh, 2010a, 2010b; Brooks, Hanafin and Langford, 2010; Richardson, 2014; Sandin, 2014). There is some variation in the role of evidence between countries. In some low- and middle-income countries aid conditionality has motivated this, while in others and in high-income countries evidence has played a role in appealing to the electorate. For example, the 1997 UK Labour government commitment to ending child poverty was strongly influenced by the UK having the highest rate of children in poverty in Europe, a major concern to Labour party supporters (Piachaud and Sutherland, 2001). Comparative data enables policies and experiences to be put in context, and differences help to raise hypotheses to explain them to further inform policy and practice (Richardson, 2014; Sandin, 2014; Bradshaw, 2015). Measures at community level can link research, policy and practice and enable agencies to carry out self-evaluation (Webster, Needell and Wildfire, 2002). Findings shared with communities are noted to have the potential to engage citizens in promoting the wellbeing of children, enhancing civic engagement around concerns for children's wellbeing and putting pressure on policy makers (Coulton, Korbin and McDonell, 2009; Coulton and Fischer, 2010; Nayowith, 2010).

The policy content stream includes the policy content and options that have been identified as feasible and credible, the policy actors/communities that are setting these options and where, how and with what evidence options are being explored. Policy experts include government officials, analysists, academics and politicians who group policy options together with the most appropriate options coming onto the agenda.

The evidence pointed to a range of findings from academic, practitioner and policy research that informed the development and selection of policies to address the problems/issues (Gabel, 2010; Aldgate, 2010; Ben-Arieh, 2010b; McAuley and Rose, 2010a; McAuley, Morgan and Rose, 2010; Sandin, 2014; Daly et al., 2015):

a. Ecological theory suggests that children's experiences contribute to wellbeing. Evidence that socioeconomic deprivation and racial and ethnic inequalities early in life have negative impacts later in life and that critical periods in early years when deprivation can alter brain structure and have negative impacts on biological functioning has led to interventions on community and social contexts to nurture their children and on measures to ensure every child has the best start in life ( Danzinger and Waldfogel, 2000; Anyabwile et al., 2003; Aldgate, 2010; Rose and Rowlands, 2010; Banati and Alexander, 2012; Daly et al., 2015; Miller and Esenstad, 2015; Pickett and Wilkinson, 2015; Alter and Meyers, 2016; Arkansas Advocates for Children and Families, 2018) . Options developed include paid parental leave, universal home visiting, income support, ECEC and community-based services. 
b. Attachment theory pointing to the importance of stable and positive relationships with adults and children in the family and community for emotional and stable development and the importance of consistent care especially in a child's first year of life has influenced policies for paid maternity leave (Moloney et al., 2013).

c. Psychologists demonstrating the importance of resilience as a protective factor in enabling children to adapt to change and in providing them with a repertoire of problem-solving approaches have motivated measures to educate children, parents and communities about resilience so that all children develop coping skills (Aldgate, 2010; Daly et al., 2015).

d. Research showing that investment in children brings better returns than investment in adults, demonstrating that quality ECEC promotes wellbeing, prevents disease and contributes to emotional and cognitive development, with lifelong impacts, for children from disadvantaged homes and immigrant children, has influenced policies to provide all children with quality ECEC (Danziger and Waldfogel, 2000; Schaefer, Gates and Kiernan, 2010; Trostel, 2013; Daly et al., 2015; Gambaro, Stewart and Waldfogel, 2015b; OECD, 2017d).

e. Evidence from states that have combined paid parental leave with ECEC showing lower infant mortality and child poverty rates than those that provide high family cash and tax benefits has influenced policies for provision of paid parental leave and ECEC for all children;

f. Attention to the importance of child wellbeing in the present and not just for their future lives, on children as social agents able to shape their own lives and make important contributions to the decisions that affect them and an understanding of 'childhood' and the 'child' as socially defined categories that are multiple and dependent on time and place has led to children being given opportunities to be consulted about polices that affect them (Aldgate, 2010; Ben-Arieh, 2010b; McAuley and Rose, 2010a, 2010b; McAuley, Morgan and Rose, 2010; Sandin, 2014).

Governments, international agencies and NGOs have funded research and evaluations of practice to inform policy, such as in the EU Framework and Horizon 2020 programmes and the UK Global Challenges Research Fund that addresses challenges faced by low- and middleincome countries. Governmental and non-governmental technical experts and officials translate evidence from research into specific policy options to address the problems/issues, and state officials and other technical actors apply innovations as pilots or programmes to test or demonstrate. The Child Health and Development Institute of Connecticut, for example, publishes policy briefs that advocate for policies by pointing to the evidence from states that have implemented these policies (CHDI, no date; Alter and Meyers, 2016). The Annie E Franklin Institute fund and rigorously evaluate policy innovations (AEF Foundation, 2013a, 2013b, 2018).

The politics stream looks at how and which political actors became engaged with the issues, what procedure/processes enabled engagement and what role political ideology, cultural norms and institutional rules have played in enabling political support.

In Chile, for example, presidents Ricardo Lagos and Michelle Bachelet played important leadership roles in both Chile Solidario (2002) (the Chilean social protection system) and Chile Crece Contigo 2007 (the benefits system for children under five) (Frenz, 2007; Franzoni and Voorend, 2011). A task force led by the Ministry of Planning with Ministries of Health and Education and the Budget Information Office designed programmes with inputs from NGOs, academics, local government and international agencies (World Bank and Inter-American Development Bank making inputs (Frenz, 2007; Franzoni and Voorend, 2011). Such political actors are found in countries at all income levels. The 1997 UK Labour government promoted investment in children as an investment for the future having built an electoral platform on a commitment to promoting child wellbeing (New Economics Foundation, 2004; Aldgate, 2010). In the Philippines, the government developed an interlinked poverty reduction and ECEC programme connected to political commitments to achieving the MDGs (Bruckauf, 2015). The South African government provides support for parenting and early childcare within a comprehensive set of health, social and educationally orientated services as part of its commitment to building a socially inclusive and cohesive society (UNICEF, no date a; Bruckauf, 2015; Daly et al., 2015). 
Policy entrepreneurs and brokers play important roles in shaping how the streams intersect, linking issues/problems and solutions with political opportunities to exploit windows of opportunity.

In terms of policy actors, UNICEF, INGOs and development partners have been key children's advocates supporting the convergence of the three streams. UNICEF has the lead advocacy role for FCHW globally and is mentioned specifically in Article 43 of the CRC as the implementing and monitoring agency. Since 1980 it has published its flagship State of the World's Children reports and in 1998 established the Innocenti Child Development Centre, which commissions and publishes research on issues affecting children, as well as league tables of child wellbeing (UNICEF, 2015a, 2015b, no date b). The OECD also publishes reports on how well member countries are doing in promoting FCHW. INGOs and NGOs play an important role in high-, medium- and low-income countries in advocating for policies and programmes to improve FCHW (Gabel, 2010; Daly et al., 2015). They often act as brokers between policy and political streams, funding and using findings from research and impact evaluations of innovative policies and practices to inform policy recommendations.

Leaders and key actors in social movements, NGOs and INGOs have also bridged social movements with technical and political actors and may sometimes become political actors themselves (Gabel, 2010). For example, Gosta Esping Andersen and Tony Giddens' writings influenced the UK Labour government's policy development towards investment states, and Tony Giddens became an advisor to Tony Blair when he was British Prime Minister (Lister, 2006).

Public intellectuals and technical actors and officials also act as policy entrepreneurs, linking policy issues, content and political streams. For instance, Amartya Sen influenced the development of the UN Human Development Index and the MDGs (Stanton, 2007; United Nations, 2015); Jeffrey Sachs played a key role in the SDGs; Jonathon Bradshaw and the Joseph Rowntree Foundation pushed reducing child poverty up the policy agenda in the UK and Asher Ben-Arieh played a key role in the child social indicators movement.

\section{Trends in FCHW policy in the USA}

\subsection{Measuring progress in promoting FCHW: How is the USA doing?}

In the context of international trends and drivers, it is important to identify policy issues, drivers and opportunities for improved policy support for FCHW in the USA, to identify where learning from other countries may be useful for this context.

Concerns are that FCHW may not be sufficiently prioritised within policies and budgets in the USA (Schellenbach, Culp and Nguyen, 2013; Edin and Shaefer, 2016; Finck et al., 2016; Organisation for Economic Cooperation and Development, 2017; The Children's Defence Fund, 2017; Annie E Casey Foundation, 2018a). The USA compares poorly on family-friendly policies such as parental leave, flexible working and childcare and is one of only three countries globally to offer no paid maternity leave (Schulte, 2014). The data in Table 2 support this. While the USA has the highest GDP among OECD countries, it is among the most unequal and compares poorly on spending on children in child wellbeing outcomes. This is despite high ranking in public spending in other areas, notably military spending, underscoring the political choices underpinning social conditions.

A 2002 comparison of child wellbeing in the USA with that of children in other high-income Englishspeaking countries (Canada, Australia, New Zealand and the United Kingdom) found that while the USA did comparatively well on indicators in the 'Safety/behaviour', 'Community connectedness' and 'Emotional wellbeing' domains, it did comparatively poorly on the 'Family economic wellbeing', 'Health' and 'Educational attainment' domains. This is consistent with what some authors refer to as a "liberal welfare regime" in the USA, with a relatively small public sector and an emphasis on a market allocation of resources and personal responsibility, compared to countries with social welfare regimes that emphasise collective responsibility and state provision of support for families in promoting the wellbeing of all children (Land et al., 2009). 
Other comparative measures indicate poor performance in the USA compared with other highincome countries and below some upper middle-income ones (See Table 3 and Appendix 1).

Table 2: USA rank among 35 OECD countries for investing in children and key child outcomes

USA rank for income and wealth

- 1 for GDP (purchasing power parity), 2016

- 4 for GDP (purchasing power parity per capita), $2016^{* *}$

- 1 for number of billionaires, 2016

- 32 for income inequality, 2015

USA rank for government spending

- 1 for military spending (in US\$), 2016

- 2 for military (\% GDP), 2016

- 8 for spending on health*** (\% GDP), 2016

- 30 for spending on ECEC (\% of GDP), 2016

- 20 for spending on education (\% GDP), 2016

- 24 for spending on family benefits (\% of GDP), $2015^{*}$

USA rank on key child outcomes

- 30 for \% children in poverty, 2015

- 33 for \% children under 15 that do not have adequate access to food, 2014/15

- 30 for \% infants weighing less than 5.5 pounds (low birthweight), 2014

- 26 for \% one-year olds vaccinated against diphtheria, tetanus and pertussis, 2014

- 32 for number of infants that die before their first birthday, 2014

- 29 for \% children under-five years enrolled in early childhood and primary education, 2014

- 20 for reading scores of 15 -year-olds, 2015

- 31 for mathematics scores of 15-year-olds, 2015

Among rich countries, the USA also has the highest number of children and teens killed with guns and is the only member of the UN that has not ratified the UN CRC.

Sources: The Children's Defence Fund, 2017: *https://www.oecd-ilibrary.org/social-issues-migrationhealth/family-benefits-public-spending/indicator/english_8e8b3273-en ${ }^{* *}$ World Development Indicators; ${ }^{* \star \star}$ including health care goods and services

Table 3: USA performance compared to other countries on child wellbeing

\begin{tabular}{|l|l|}
\hline Measure & USA rank \\
\hline UNICEF League Table of Child Wellbeing in Rich Countries 2013 & $26 / 29$ \\
\hline Child Prosperity Index & $9 / 19$ \\
\hline Country Performance Across Nine Child Relevant SDG Goals & $37 / 40$ \\
\hline League Table of Inequality & $18 / 35$ \\
\hline Child Life Satisfaction Scale & $23 / 29$ \\
\hline End of Childhood Index 2018 & $36 / 175$ \\
\hline
\end{tabular}

Source: See evidence in Appendix 1

The evidence suggests limited progress in the USA in a number of measures of investment in children or child wellbeing. There has been no improvement in child poverty rates or in overall child wellbeing since the 1980s (Land, 2014b; Federal Interagency Forum on Child and Family Statistics, 2017). Between 2004 and 2014, the average spend per child on welfare services (federal, state and local funding) fell by 3\% (Connelly and Rosinsky, 2018a). The 2017 Children's Budget shows that between 2014 and 2017 the share of federal budget invested in children fell from $8.2 \%$ to $7.4 \%$ and by 2017 it was $2.6 \%$ lower than in 2008 (Linden et al., 2008; Merker, 2017). There has been a real decline in funding for child welfare and the President's budget proposal for 2018 included a $3 \%$ cut in the budget for children (Merker, 2017).

The Child Wellbeing Index shown in Figure 1 correlates with state and local tax rates, level of Temporary Assistance for Needy Families (TANF) benefits, per pupil expenditure on elementary and secondary education, and access to public medical insurance programmes (as well as the KIDS COUNT index published annually by the Annie E Cassey Foundation). It shows no overall improvement since the 1980s (O'Hare et al., 2013). 
While there have been noticeable improvements in 'Safety' and 'Community connectiveness' there have been noticeable declines in 'Health', 'Emotional' and 'Social relationships' and little change in the 'Economic' and 'Education' domains. Relative inequalities between white, black and Hispanic children have remained unchanged. While the wellbeing of infants has improved, that of children has worsened, with little change among adolescents (Land, 2014a, 2014b). Compared to white children, Hispanic, black, American Indian/Alaska native, native Hawaiian/other Pacific Island, mixed race children and immigrant children do less well in the economic domain (The Children's Defence Fund, 2017). Immigrant children do as well or better than children of native-born families on seven of the thirteen indicators (Hernandez and Cervantes, 2011). However, they face significant barriers accessing programmes aimed at safeguarding children in poor families, and their immigration status and level of proficiency in English can further limit their access to public services.

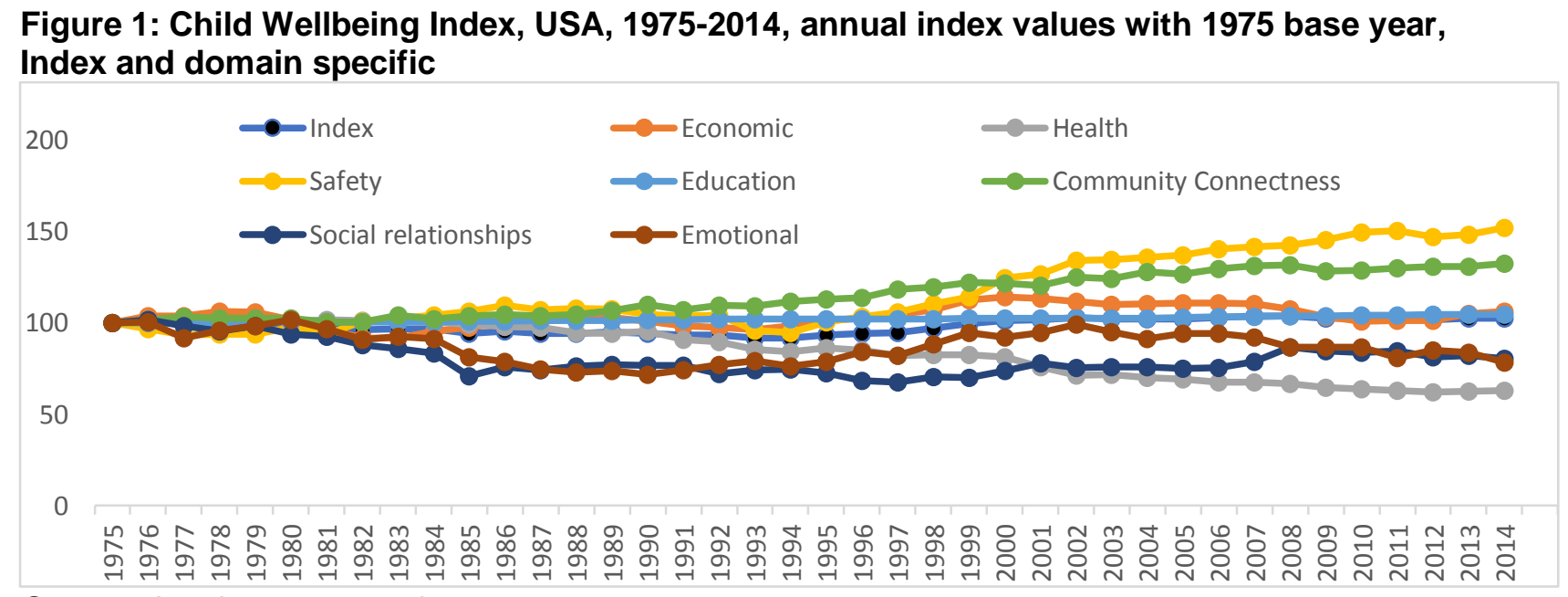

Sources: Land, 2014a, 2014b.

Wellbeing also varied significantly by state. Compared with 1990 little change has been documented in the rank order of states on the KIDS COUNT index with only four states having moved up 10 or more places (Illinois, Virginia, Idaho Tennessee and Georgia), and four moving down 10 or more places (Nevada, Alaska, Oregon and Rhode Island (See Appendix 1). Figure 2 shows the rank order of states on the KIDS COUNT Index by GDP per capita, with one being the highest rank and 50 the lowest. The figure illustrates which states are using their dollars to promote child wellbeing. Those above the trend line are investing more in children than would be predicted from their GDP and those below, less. For example, New York has the second highest GDP per capita but is ranked 32 on the KIDS COUNT Index. New Mexico is ranked 39 for GDP per capita but is ranked the lowest (50) on the index. Conversely, Idaho, ranked 49 for GDP per capita, is ranked 21 on the Index, and Maine, ranked $43^{\text {rd }}$ for GDP per capita is $16^{\text {th }}$ on the index.

NGOs, child advocacy groups and media use these indicators, as do political entrepreneurs, to make the case for policy interventions to improve FCHW. For this they need to be presented in a relevant form to policy makers and 'agents of change' (Ben-Arieh and Goerge, 2006; National Institute on Drug Abuse, 2007). In New Mexico, for example, Voices for Children have prepared a guide on how public policy can improve child outcomes for each of the domains on the KIDS COUNT Index, what New Mexico can do to improve outcomes for children and their families and what improvement in outcomes is needed to move New Mexico up five places to first place on the index (Wallin, 2018). The report was published to influence politicians in advance of the 2018 elections.

\subsection{Levels of and contexts for policy recognition of FCHW in the USA}

The USA, as in other high-income countries, faces demographic pressures (described above). It has high and increasing socioeconomic, race and gender inequalities and spatial segregation (Standford Centre on Gender and Poverty Inequality, 2011; Edin and Shaefer, 2016). There are economic and racial inequalities in child wellbeing with Afro-American, Native American and immigrant children especially disadvantaged (Centre for the Study of Social Policy, 2006; 
Hernandez and Cervantes, 2011; Annie E Casey Foundation, 2015; Miller and Esenstad, 2015). The USA is also on the cusp of a radical shift in demographics, with many young children being children of colour, with competing trends of populism versus multiculturalism, and liberal versus conservative/isolationist values.

\section{Figure 2: USA States' successes in translating wealth into child wellbeing, rank order on 2018 KIDS COUNT Index and 2017 GDP per capita}

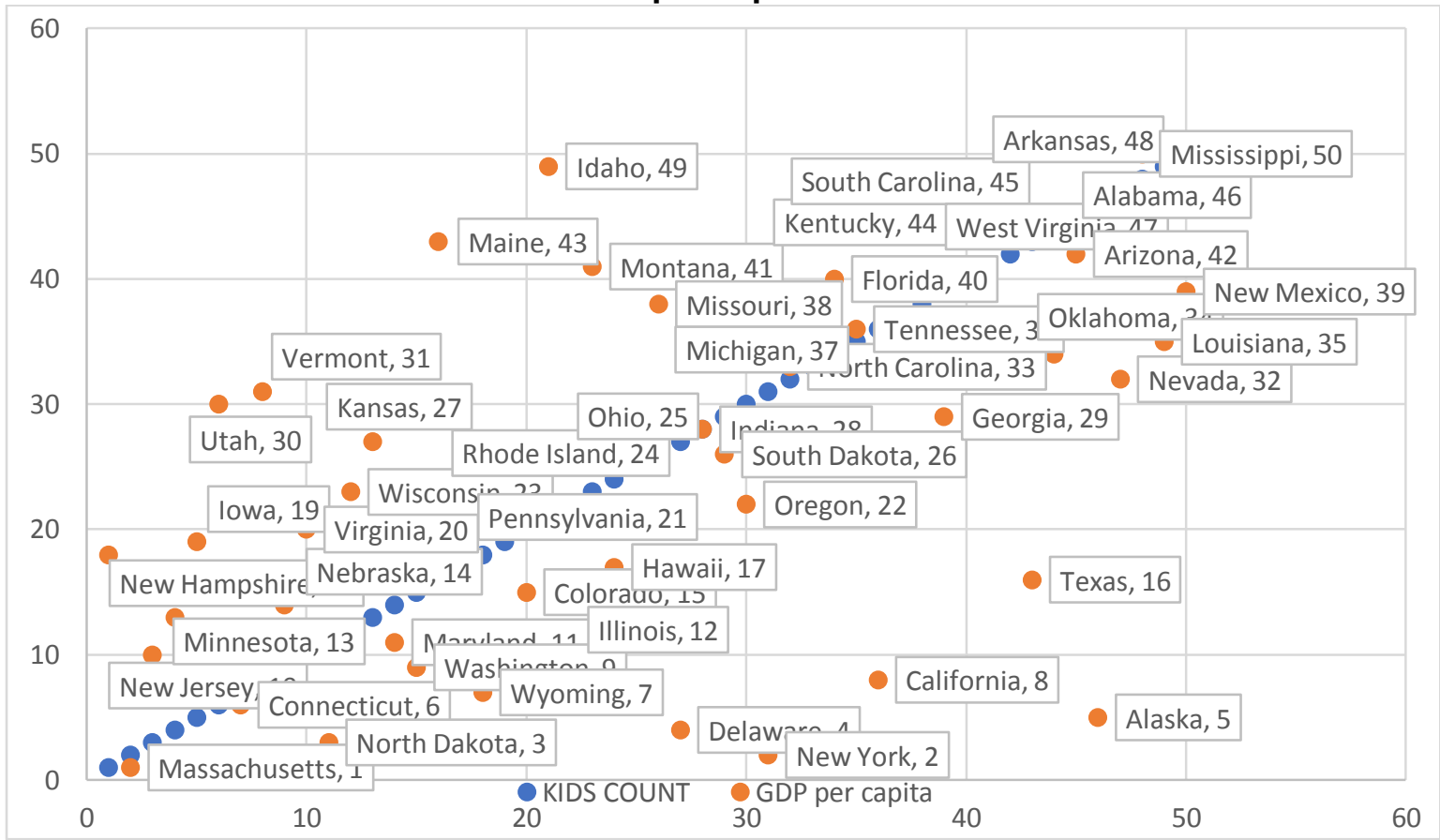

Sources: https://www. statista.com/statistics/248063/per-capita-us-real-gross-domestic-product-gdpby-state and http://www.aecf.org/resources/2017-kids-count-data-book/

The legal framework in the USA is underpinned by principles of individual liberty and autonomy with weak commitments to collective responsibility affecting policy choices (Huntington and Scott, 2015). While other welfare states are converging in expenditure and policies they have increased in distance from the USA (Starke, Obinger and Castles, 2008). Policy in the USA remains focused on protecting children from abuse and neglect and ending dependency on benefits, rather than reducing child poverty or helping all families to raise healthy children (Kamerman and Kahn, 2002; Shields and Behrman, 2002; Waldfogel, 2010; Pecora and Harrison-Jackson, 2010;

Bogenschneider, 2011; Mistry et al., 2012; Mallon and Hess, 2014a, 2014b; Currie and Reichman, 2015; Huntington and Scott, 2015; Brown, 2016; Kemp et al., no date). There is limited recognition of the importance of government in supporting parents or providing adequate financial support for all poor families, despite evidence that the main predictor of child abuse and neglect is poverty (Palley and Shdaimah, 2014; Finck et al., 2016; Gadsden, Ford and Breiner, 2016). Reforms to the benefits system in the 1990s moved many families from poverty on benefits to in-work poverty and drove the poorest families that remained dependent on welfare even deeper into poverty (Waldfogel, 2006, 2010; McGowan, 2014; Edin and Shaefer, 2016; Hoynes and Schanzenbach, 2018). There is no legal entitlement to paid parental leave with only $14 \%$ of civilian workers having access to parental leave, and limited, often poor quality ECEC (Waldfogel, 2007, 2010; Magnuson and Waldfogel, 2014; The National Academies of Sciences and Medicine, 2016; Brainerd, 2017). Poor quality may be linked to low wages in ECEC settings. Many ECEC workers are paid minimum wages, with high levels of food insecurity reported to affect both workers' health and child wellbeing outcomes (Ludden, 2016; RWJF and Changemakers, no date).

Supporting families and children is reportedly a low spending priority (AACF, 2018; Children Now, 2018; The Children's Defence Fund Cailfornia, 2018). Among OECD countries only Mexico and Turkey spend less of their GDP on publicly funded family benefits (OECD, 2017a; Hoynes and Schanzenbach, 2018; The Children's Defence Fund Cailfornia, 2018). Furthermore, spending on children is predicted to decline from $10 \%$ to $7 \%$ of the federal budget over the next decade with 
only $1 \%$ of the predicted $65 \%$ increase in federal spending allocated to children (The Children's Defence Fund, 2017; Hamm, Schochet and Novoa, 2018; Schott and Pavetti, 2018).

There is no explicit family policy or coherent package of policies for children and families, and policies with consequences for children are reported to be limited in coverage and narrowly focused (McCroskey, 2006). FCHW is generally profiled in terms of the wellbeing of children at-risk or in the welfare system. Family policies and laws are transitory and prone to changes in federal and state administrations, with little consistency between levels (Fitzpatrick and Kostina-Ritchey, 2014). The child welfare system is described as having developed in a piecemeal manner and as lacking in coherence (McCroskey, 2006). There is general lack of policy on the structural causes of problems that poor families experience. Policies instead target individual behaviours, such as parenting skills (Seccombe, 2002; Robbins and Fremstad, 2016).

Child advocacy NGOs argue that children are not high on the political agenda and that there is a lack of a powerful and co-ordinated lobby for FCHW, limited discussion about prioritising FCHW, with children reportedly losing out to other interests and priorities (Children Now, no date; Annie E Casey Foundation, 2017; The Children's Defence Fund Cailfornia, 2018; The Children's Partnership and The Children's Defence Fund California, 2018; McGowan, 2014; Annie E Casey Foundation, 2017; Hoynes and Schanzenbach, 2018). The USA has not domesticated the CRC and we found no evidence of UNICEF or other international agencies actively promoting FCHW in the country.

In terms of social and cultural norms and values, responsibility for the wellbeing of children is seen almost entirely as the responsibility of parents (Cahn and June, 2010, 2014; Palley and Shdaimah, 2014). Several authors noted that parents are seen as having the right to raise their children as they see fit, using the 14th amendment of the USA Constitution (although it does not explicitly protect parental rights, there are numerous examples of case law in which it has successfully been invoked for this purpose) (Walker, Brooks and Wrightsman, 1999; Bartholet, 2011; Davidson, 2014; Fitzpatrick and Kostina-Ritchey, 2014; Huntington and Scott, 2015). Many documents describe the family as a private sphere, with the state only having the right to intervene when things go wrong. State provision of services for children is seen to undermine parental authority, allow parents to abdicate their responsibilities and potentially behave irresponsibly by having children they cannot afford to support (Fitzpatrick and Kostina-Ritchey, 2014; Sandin, 2014; Currie and Reichman, 2015). The replacement of Aid to Families with Dependent Children (AFDC) with the 1999 Temporary Assistance to Needy Families (TANF) under the Personal Responsibility and Work Opportunity Reconciliation Act (PRWORA) 1996, for example, was designed to deter out-ofwedlock births and encourage the formation and maintenance of two-parent families, albeit with limited success (Connelly and Rosinsky, 2018a, 2018b; Lichter, 2018). A strong lobby for traditional family values is documented to have effectively blocked some areas of progressive legislation on FCHW (Kamerman and Kahn, 2001).

There is evidence that government policy may be out of line with public opinion. There are reports that Americans see investing in children as important and want government to address these concerns (Waldfogel, 2010; Annie E Casey Foundation, 2016). According the Annie E Casey Foundation (2016), voters agree that there should be social insurance to enable families to mitigate health crises and unemployment. Other sources report that: Americans agree about the importance of equal opportunities for all children, including those from ethnic, racial and religious minority communities; they see healthcare, child poverty, ECEC and education as key issues and; governments should help poor families (American Humane Association, 2015; Udall, 2015; Cox and Jones, 2017). They also identify major problems in harmful drug use and addiction, in physical and emotional abuse and in poor parenting (American Humane Association, 2015; Cox and Jones, 2017). There is a perception that state and local governments are likely to do what is right but there is a strong distrust of federal government (Cox and Jones, 2017). This suggests that the problem/issue stream and the policy content and political streams are not converging in their norms, even though there are policies that would implement changes in line with the public preferences. It further suggests that an imbalance in public opinion and policy is necessary but may not be sufficient to cause shifts in policy making. 
The federal system of government is reported to make it difficult to create coherent FCHW policies, with fragmentation disrupting access (Curran, Houshyar and Lesley, 2012; Sandin, 2014). Federal laws provide frameworks within which states deliver programmes and use funding levers for their implementation. Although federal laws can be written to allow state flexibility, they were often described as restricting the extent to which states can develop their own policies and services for FCHW. State child and family services are reported to be underfunded, with significant variations in state spending and service delivery (Curran, Houshyar and Lesley, 2012; McGowan, 2014; Edwards, 2016a; Connelly and Rosinsky, 2018a, 2018b). Federal funding promotes foster care and adoption over preventive services for children at risk and their families (Centre for the Study of Social Policy, 2009). Approximately half of federal funding is earmarked for foster care, adoption and guardianship services with only $11 \%$ for demonstration waivers used for preventive programmes. Title-IV-B can be used more flexibly, including providing services for children at risk and for foster and adoptive parents. It makes up only $5 \%$ of federal spending, however, and the funding level depends on an annual appropriation. States can also access nondedicated funding streams, including Medicaid and the Social Services Block grant. States need to match funding for much federal funding, so policy implementation is influenced by the amount and consistency of federal funding. There are also conditions tied to federal funding that can make it difficult to develop innovative state programmes for FCHW.

\subsection{Areas of increased FCHW policy recognition in the USA}

There are, howeve, r several opportunities for improved FCHW policy recognition in the USA. At federal level these include attention to: improving educational outcomes; increasing health insurance for poor families; improving nutrition for poor children; providing income support for poor families; and providing services for vulnerable/at-risk children. In this section, we explore further the features and differences in FCHW policy recognition among states in the USA.

Access to quality education and ECEC: At federal level there has been a concern to reduce inequalities in educational outcomes. The No Child Left Behind Act 2002 grew out of a concern that schools were not internationally competitive. It put a special emphasis on states boosting performance among poor and minority children, including immigrant children (Klein, 2015). The law has been heavily criticised, however, for little evidence that it has reduced inequalities in educational outcomes and for an over-emphasis on testing (Klein, 2015). It was replaced in 2015 by the Every Child Succeeds Act requiring all schools to have continuous improvement plans and targeted efforts to improve poorly performing schools (Klein, 2015, 2016, 2018). There is, however, no national debate about ECEC despite evidence of its importance in improving educational outcomes. The USA remains the only OECD country that does not provide at least one year of universal free pre-school education (Magnuson and Waldfogel, 2014; Palley and Shdaimah, 2014; Howard, 2018b). This presents as a potential area for policy recognition, given issues of poor access, quality and affordability. Low-income families pay higher proportions of their income for poor quality ECEC than more affluent families do, and only about half of eligible three- and fouryear-olds are in ECEC (Workman et al., no date; Blau, 2002; Herbst and Tekin, 2010; Magnuson and Waldfogel, 2014). Interestingly, the state-provided military childcare system is seen as a model for access, quality and cost (Magnuson and Waldfogel, 2014). There are also state innovations. For example, the First 5 California programme provides incentives for early care providers to participate in specialised infant/toddler training (Alter and Meyers, 2016). King County, Washington, has introduced a property tax levy to raise $\$ 65$ million a year for six years at an annual average cost to homeowners of one dollar, with half the revenue invested in ECEC (Alter and Meyers, 2016).

Improving incomes of poor families: Short- and long-term payoffs for individuals and society have been identified in programmes that increase incomes of poor families, reduce child poverty and improve school performance and health outcomes associated with increased earnings and employment when children reach adulthood (Sherman, Trisi and Parrott, 2013; Sherman and Tazar, 2017). On the positive side, reforms in the 1990s to the 'work support system' (earned income tax credits [EITCs], child tax credit [CTC], food stamps, and Medicaid) lifted many working families out of poverty (Waldfogel, 2010; Currie, 2018). However, reductions in the real value of cash assistance, the strict eligibility tests, and increases in the numbers deemed ineligible meant that workless families were driven into deep poverty (Sherman, Trisi and Parrott, 2013; Edin and 
Shaefer, 2016; Floyd, Pavetti and Schott, 2017; Currie, 2018; Hoynes and Schanzenbach, 2018; Shaefer and Edin, 2018). In a key federal focusing event in 2008, Nancy Pelosi, the Speaker of the House of Representatives, convened a Children's Summit at which legislators and policymakers discussed programmes to address child poverty. It discussed measures to address the negative impact of the 2008 economic crisis, including expanding programmes such as unemployment insurance, EITC, and food stamps via the Supplemental Nutrition Assistance Program (SNAP), which benefit low income families (Waldfogel, 2010). When President Obama came to office the following year there was an increase in the value of food stamps for non-working lone parents, and families with three or more children benefited from an increase in EITC. The Healthy Hungry-Free Kids Act 2010 set standards for core nutritional programmes and has been reported to increase access for vulnerable, low-income children and poor mothers by offsetting costs of food for poor families (Hernandez and Cervantes, 2011; Nolen, 2014). It was estimated that these measures would lift 2.4 million children out of poverty (Sherman, 2009). They mitigated the impact of the recession on working families but not for workless ones (Bitler, Hoynes and Kuka, 2014). As state innovations, Vermont, California and Massachusetts have established work exemptions for single parent heads of households on TANF until their child is 24 months (Alter and Meyers, 2016). However, federal spending on family benefits declined from $0.8 \%$ of GDP in 2000 to $0.7 \%$ in 2013 , and past gains for poor working families are reported to be under attack from the current administration. Benefits are being cut to support $\$ 1.5$ trillion tax cuts and there are suggestions that strict work requirements may be imposed for eligibility for assistance programmes including SNAP and Medicaid without impact assessment (OECD, 2017b); The Children's Defence Fund, 2017; Hamm, Schochet and Novoa, 2018; Mitchell, 2018; Schott and Pavetti, 2018).

Enhancing health care coverage: The 1997 Children's Health Insurance Programme (CHIP) extended health insurance to poor children not eligible for Medicaid (Waldfogel, 2010). However, CHIP may not have increased enrolment among those ineligible for Medicaid in families just above the federal poverty line; they remain less likely to be insured than children from wealthier or poorer families (Saavedra, 2017). The 2010 Patient Protection and Affordable Care Act (ACA) aimed to improve access to medical care. States can also expand Medicaid to uninsured children and adults with incomes up to $138 \%$ of the Federal Poverty Level (FPL). Those who fall above the threshold but below $400 \%$ qualify for subsidies to help cover the cost of care through the exchanges. These measures extend coverage to all low-income households, including working families (Sherman, Trisi and Parrott, 2013). For example, in New York State Child Health Plus enables children in lowto medium-income households not eligible for Medicaid to get insurance. The ACA also promoted child wellbeing through public health provisions including maternal, infant and early childhood home visits (Fuemmeler et al., 2017). It too is reported to be under attack from the current administration.

Support for and placement of vulnerable children: With around one million substantiated cases of child abuse and neglect per year and the lifetime cost of one year of substantiated claims estimated at \$124 billion, this is a serious social problem (Curran, Houshyar and Lesley, 2012; Finck et al., 2016). Children from poor homes and especially Afro-American and Native American children are at greatest risk of being in care and, when in care, placed in group settings (Centre for the Study of Social Policy, 2006; Hernandez and Cervantes, 2011; Annie E Casey Foundation, 2015; Miller and Esenstad, 2015). There is recognition of this, but mainly for children at risk of being taken into care or for those already in the welfare system (Hartnett et al., 2009; Pecora and Harrison-Jackson, 2010; Centre for the Study of Social Policy, 2013; Mallon and Hess, 2014a and 2014b; McGowan, 2014; Blue Ribbon Commission, 2016; Illinois Department of Children and Family Services, 2016; Stoltzfus, 2017). While child welfare agencies are charged with ensuring the wellbeing and safety of at-risk children and their permanent placement with a family, this can be open to interpretation. It has been reported to be taken to mean the provision of minimally adequate services (Hartnett et al., 2009; Jordan and Connelly, 2016).

Since 2000 the USA Child and Family Service Reviews have given more focus to outcomes in this area rather than just process of programmes with federal funding (Curran, Houshyar and Lesley, 2012; McGowan, 2014). The Fostering and Connections to Success and Increasing Adoption Act (FCSI) 2008 mandates attention to the promotion of wellbeing of children in the welfare system, albeit with a focus on safety (Mallon and Hess, 2014a and 2014b). There is scope for policy focus 
in this area. The moves to place more children with relatives if they cannot live with their parents is generally in children's interest but restrictions on the use of federal funding for care providers can mean that they do not receive the support they need. Federal funding for welfare services also makes it difficult for states to provide preventive services and to support children returning to the care of parents or alternative relatives (Annie E Casey Foundation, 2015). States were also reported to have difficulties finding permanent placements with families for older children and young people (Schalick, 2014). However, FCSI confers a range of benefits: extending the option of guardian assistant payments to relatives of children who have been in foster care and making them eligible for Medicaid; permitting funding to be used for preventive/reunion services; providing for additional incentives for adoption; providing for states to deliver short-term training for relative guardians and service personnel; and making additional provisions to improve outcomes for young people over 16 years to make smoother and more successful transitions out of care (McGowan, 2014; Child Welfare Information Gateway, 2016).

The Family Services Prevention First Act 2018 has been welcomed as a historic reform to the welfare system. It aims to improve outcomes for vulnerable children and the wellbeing of children already in care by incentivising states to reduce placement of children in congregate care (First Focus, 2018; The Children's Defence Fund, 2018). The Act reforms child welfare funding so that Title IV-E funding can be used for prevention services (mental health services, substance abuse treatment, in-home parenting skills training) to families whose children are at risk of being taken into care. It requires that children are only placed in residential homes that provide treatment programmes. Estimates of the additional funding to preventive services suggest that it will be about $\$ 130$ million: a minuscule amount compared to the billions spent on foster care. Authors also forecast that under the Act, the proportion of foster children in homes and institutions would only decline from $14 \%$ to $11 \%$ over ten years (Wexler, 2018). Furthermore, preventive funding is not for services to prevent abuse or neglect, but to prevent children's entry into foster care once abuse has already occurred. The Act does nothing to address two key issues: the shortage of foster homes and the poor quality of care that many give; and the outdated link between Title IV-E funding and AFDC eligibility, which has not been updated since the 1990s and reportedly limits states' abilities to pull down federal funding (Anon., 2018a, 2018b).

States have, however, taken innovative measures. Twenty-five states and the District of Columbia are reported to have used Title IV-E and TANF demonstration waivers to pilot innovative approaches to child welfare service delivery. These include programmes to reduce the number of children that need to be taken into care, to prevent child abuse and improve treatment for children with challenging behaviour. Evaluations suggest that programmes may be: reducing the risks of child abuse; preventing children having to come into care; improving parenting skills; child and family physical and emotional health; and educational development (James Bell Associates, 2016). In Minnesota, following representation by African American families with children in the welfare system, a State Advisory Committee was set up and the state's administrative data system was developed to disaggregate data by race to enable targeted preventive interventions. One county was able to identify schools with high rates of suspected child abuse and develop strategies to identify and meet the needs of families before a crisis (Miller and Esenstad, 2015).

Strengthened non-state and community initiative and advocacy: A number of NGOs and child advocacy groups were identified that advocate for policies and programmes to promote FCHW (Nayowith, 2010; Curran, Houshyar and Lesley, 2012). While these NGOs are committed to promoting wellbeing for all children, they find that they often have to put efforts into protecting limited welfare gains already made (The Children's Defence Fund, 2017). We found three states where NGOs have published policy briefs for improving child wellbeing: California (Children Now, 2018; The Children's Defence Fund Cailfornia, 2018; The Children's Partnership and The Children's Defence Fund California, 2018); New Mexico (New Mexico Voices for Children, 2013, 2018; Wallin, 2018) and Arkansas (AACF, 2018). All are arguing for services to improve the living conditions of poor families and their children, including: increased financial support; improved health insurance coverage; a quality education for all children, including ECEC; and preventive services for children at risk. The Citizens' Committee for Children has influenced policy developments in New York City that have positively affected the health and wellbeing of poor children and their families. It had done so by using research findings and identifying service needs 
among New York families to make policy recommendations for programme planning and resource allocation (Nayowith, 2010).

Several promising initiatives were identified of federal, state and local efforts to shift from focusing on safety and permanency to fostering resilience and promoting child wellbeing in the welfare system (Webster, Needell and Wildfire, 2002; Centre for the Study of Social Policy, 2013; McGowan, 2014; Corwin, Pecora and Ostrum, 2016). These were often supported by NGOs, but also made use of the ways states can use federal funding more flexibly. However, these interventions tended to be uncoordinated with piecemeal provision and were generally pilot projects with time limited funding. We identified ten types of initiatives that promote wellbeing for children at-risk or in the welfare system. The most extensive of these are community-based support initiatives provided in a number of states, mainly with the support of the Annie E Casey Foundation or the Casey Family Foundation (Annie E Casey Foundation, 2013a; McGowan, 2014; Berger and Font, 2015; Casey Family Programmes, 2016; Corwin, Pecora and Ostrum, 2016; Clara, Garcia and Metz, 2017). A key lesson reported in evaluations of these initiatives is the importance of strengthening communities in addressing the needs of children and parents. For example, the Engaging and Empowering Residents in Indianapolis project aimed to give residents information and data about their communities, grants to pay for their work, leadership training and support in setting up study circles. Residents came to recognise that they had many concerns in common. The residents of one block were able to use a Learning Circle to successfully lead a campaign against the landlord's petition to change its zoning (Annie E Casey Foundation, 2013a). Other community level initiatives included:

- Home visiting/parental training programmes (Nayowith, 2010; Berger and Font, 2015; Alter and Meyers, 2016). For example, the Durham Family Initiative aims to improve family wellbeing and reduce child maltreatment. Following a pilot phase, it has been scaled up to a community-wide home visiting programme (Corwin, Pecora and Ostrum, 2016).

- Community schools in deprived neighbourhoods, such as one in New York City, open from 7 a.m. to 10 p.m., offering services to children, families and community members; including before- and after-school activities, adult evening classes that include parenting skills, health dental and social services (Cash and Anderseon-Butcher, 2006; Dryfoos and Nissani, 2006).

- Community-based family resource centres for high-risk families already in the welfare system (McCroskey, 2006). For example, the Families and Communities Together Initiative in Orange County supports family resource centres working with families and communities to prevent children having to be taken into care (Orange County Social Services Agency, no date).

- Interventions to improve health outcomes (Carter et al., 2006; Policy for Results, 2012; Hoagwood et al., 2014; Rosanbalm et al., 2016). For example, in New York City the Citizens Committee for Children of New York (CCV) partnered with city authorities to introduce the Green Carts Scheme to increase the availability and affordability of nutritious food in poor neighbourhoods, enabling families to make better food choices (Nayowith, 2010).

- Provision of comprehensive, critical support to children and families under a broader approach to shift the culture of communities towards positive environments where children can thrive. For example, the Harlem Children's Zone started as a one-block project in the 1990s under the ethos: "the success of our children and the strength of the community go hand in hand" (OII, 2018; PNI, 2018). It came to serve as the model for the federal Promise Neighbourhoods programme (authorised under Elementary and Secondary Education Act of 1965 [ESEA])".

These preventive and community-based programmes are important because increasing family incomes, home visiting programmes and community-level primary prevention programmes can improve FCHW (Berger and Font, 2015). Given that services for at-risk children kick in once incidents have occurred, investing in preventive services would reduce costs and improve child wellbeing (Finck et al., 2016).

The main FCHW concerns that have been raised in the USA since 2000 are thus:

- Improving educational outcomes generally and especially for children from poor and ethnic minority families and lack of universal public provision of ECEC.

- Reducing child poverty and workless families pushed into deeper poverty, addressing attacks by the present administration on gains made in the 1990s and 2000s for in-work poor families. 
- Increasing affordable health insurance coverage for poor and middle-income families and improving the health of poor children by having nutritional standards for core programmes such as school meals.

- Improving the wellbeing of vulnerable children and their families by providing services to support poor parents in raising children, to prevent children having to be taken into foster care, and improving the wellbeing of children in care by putting more emphasis on outcomes.

- Strengthening community, local and state led innovations, initiatives and advocacy.

Many of these positive interventions in the USA have in common that they:

- Draw on research on current conditions and evidence of what works; and build in evaluation so that programmes that work can be scaled up and others can learn from them.

- Recognise that parenting is influenced by: multiple environments from the home through the community to wider society; espouse a collective responsibility for FCHW; and provide community-based support services for vulnerable families.

- Acknowledge that families involved with the welfare system have problems rather than being the problem; that to improve child wellbeing it is also necessary to improve parents' wellbeing and enable them to gain parenting skills.

- Recognise the importance of stability in children's lives and of supporting families in child welfare and fostering so that children do not have to be taken into care, and that if they are, reunification with their parents or other family members should be the first option; and that every effort is made to place children in non-kin care in families in the community.

- Focus on outcomes rather than processes in relation to education and health initiatives, and for children in care, to improve child wellbeing and ensure that children have a good start in life.

- Are often initiated by NGOs able to bring together those affected and the technical and political actors using evidence and contacts at local and state level.

- Prioritise multi-sectoral partnerships to support and advocate for community-based initiatives, involving NGOs, public and private sectors, strengthening communities and recognising that the neighbourhood environment impacts on the FCHW (Rossen, 2014; McCarty, 2016).

- See children as playing an active role in their own lives, and recognising that children need to enjoy childhood as well as grow up prepared for adult life.

\subsection{Features of and differences in FCHW policy in the USA}

As noted earlier, many states applying innovations in FCHW and learning from other countries may reinforce and enhance uptake of positive actions. In the USA, states are responsible for service delivery within the framework set by the Constitution and the federal government. Services for families and children are funded by a combination of grants from the federal government and state revenues and the spending levels on services vary across states (Connelly and Rosinsky, 2018b, 2018a). The decentralisation of FCHW policies has been reported to shape geographical inequalities across states (Bruch, Meyers and Cornick, 2018). In general, five welfare regimes have been identified and correlated with the level of support for low-income families (Table 4) (Meyers, Gornick and Peck, 2001). As a result, the states in which children and their families live determines access to services and programmes and the extent to which these promote FCHW (Meyers, Gornick and Peck, 2001; Cahn and June, 2010; Palley and Shdaimah, 2014). The evidence also suggests that states holding traditional conservative values in the Bible Belt, the mountain west and rural America appear to have the highest rates of family instability (Cahn and June, 2010).

Access to state funded/subsidised ECEC varies widely: seven states (Idaho, Montana, New Hampshire, North Dakota, South Dakota, Utah, Wyoming) have no programme for three- or fouryear olds; only two states (Florida and Vermont) and the District of Columbia have more than three-quarters of four-year olds enrolled in state-funded preschools; and only one state (Vermont) and the District of Columbia have more than half of three-year olds enrolled (The National Institute for Early Education Research, 2018). Spending also varies by state although there is less variability in meeting quality benchmarks. Average state spending per child in 2016 - 17 was $\$ 5,008$ but it varied from the District of Columbia, which spent $\$ 16,996$ per child, to Nebraska, which spent less than $\$ 2,000$, and with six other states spending less than $\$ 3,000$ (see Appendix 1). 
Table 4: Welfare regimes, main characteristics and states, USA

\begin{tabular}{|l|l|l|}
\hline $\begin{array}{l}\text { Welfare } \\
\text { regime }\end{array}$ & Main characteristics & States \\
\hline Minimal & $\begin{array}{l}\text { Minimal support, well below the national average } \\
\text { even allowing for differences in cost of living and } \\
\text { a high tax burden on families and low levels of } \\
\text { programme inclusion. }\end{array}$ & $\begin{array}{l}\text { Alabama, Arkansas, Kentucky, } \\
\text { Louisiana, Mississippi, South } \\
\text { Carolina, Tennessee, Texas, West } \\
\text { Virginia }\end{array}$ \\
\hline Limited & $\begin{array}{l}\text { Limited income support, inclusion and adequacy } \\
\text { below the all-state average apart from childcare, } \\
\text { preschool and tax relief which were at the all- } \\
\text { state average. }\end{array}$ & $\begin{array}{l}\text { Arizona, Delaware, Florida, Georgia, } \\
\text { Missouri, North Carolina, New } \\
\text { Mexico, Nevada, Oklahoma, Virginia }\end{array}$ \\
\hline Conservative & $\begin{array}{l}\text { Low on income support, employment and support } \\
\text { through the provision of childcare and preschool } \\
\text { but average on tax policies benefiting the working } \\
\text { poor. Noticeably higher than average on policies } \\
\text { enforcing private responsibility - collection of } \\
\text { child support and forcing benefits recipients into } \\
\text { employment related activities. }\end{array}$ & $\begin{array}{l}\text { Idaho, Indiana, Kansas, Montana, } \\
\text { North Dakota, Nebraska, South } \\
\text { Dakota, Utah, Wyoming }\end{array}$ \\
\hline Generous & $\begin{array}{l}\text { Generous package of cash assistance, and } \\
\text { higher than national average spending on } \\
\text { childcare and pre-school and average for tax } \\
\text { policy, child support and support for entry into } \\
\text { employment. }\end{array}$ & $\begin{array}{l}\text { California, Colorado, Connecticut, } \\
\text { lowa, Illinois, Massachusetts, Maine, } \\
\text { Michigan, New York, Oregon, } \\
\text { Pennsylvania, Rhode Island, } \\
\text { Washington }\end{array}$ \\
\hline $\begin{array}{l}\text { Integrated package of support scoring above the } \\
\text { average on all dimensions. Generous inclusive } \\
\text { cash assistance and in-kind benefits combined } \\
\text { with progressive tax policies, commitment to } \\
\text { employment support with high levels of child } \\
\text { support collections and a commitment to } \\
\text { supporting entry to employment. }\end{array}$ & $\begin{array}{l}\text { Maryland, Minnesota, New } \\
\text { Hampshire, New Jersey, Ohio, } \\
\text { Vermont, Wisconsin }\end{array}$ \\
\hline
\end{tabular}

Source: Meyers, Gornick and Peck, 2001.

States vary in access to income support and services for poor families and in the economic value of the support (Edwards, 2016a, 2016b; Floyd, Pavetti and Schott, 2017). Under the TANF Act 1996, the lifetime limit for unemployed lone parent mothers receiving a cash income is 60 months.

However, in implementing the law, 16 states imposed shorter time limits and 20 states required engagement in work before application, rather than after two years on benefits (Waldfogel, 2010). In 2014 , it was reported that poor families getting cash assistance (TANF) in a state near the $10^{\text {th }}$ percentile received an average benefit of $\$ 1,957$ while a comparable poor family in a state near the $90^{\text {th }}$ percentile received an average benefit of $\$ 5,811$ : a $66 \%$ difference (Bruch, Meyers and Cornick, 2018). There has also been a sharp reduction in the proportion of eligible families getting TANF cash assistance and/or support with employment, with funds used for other programmes that benefit families with higher incomes (Floyd, Pavetti and Schott, 2017; Ura, 2017; Hoynes and Schanzenbach, 2018; Mitchell, Pavetti and Huang, 2018; Schott, Floyd and Burnside, 2018). In 2016, for example, it was reported that for every family in poverty only 23 in 100 received TANF cash assistance compared to 76 in every 100 in 1995, varying across states from 5\% to $62 \%$ in 2016 (Edwards, 2016a; Floyd, Pavetti and Schott, 2017; Hoynes and Schanzenbach, 2018). In fifteen states only $10 \%$ or less of eligible poor families receive it and only in two states do more than $50 \%$ of these families (Hoynes and Schanzenbach, 2018). States in the South have consistently low TANF benefit rates after adjusting for regional differences in cost of living (Edwards, 2016a). States assisting fewer families pay lower benefits and those assisting more tend to pay higher benefits. In Kansas, for example, the consequences of tightening the eligibility criteria meant that families no longer entitled to TANF were struggling to survive with work unsteady for most and wages below the poverty line. Four years after exiting TANF median earnings were just $71 \%$ of what they would have received with no earnings and full benefits (Mitchell, Pavetti and Huang, 2018). Furthermore little consideration is reportedly given to how the wellbeing of children and their families cut off from TANF can be safeguarded (Mitchell, 2018). 
While there is variation in federal support and services, states and local authorities do have latitude for and experience of positive innovation in FCHW. For example:

- At least two counties, Shelby, Tennessee, and Santa Clara, California committed to promoting FCHW and ensuring that all children are healthy, safe and nourished and use child impact statements to measure the potential impact of existing and proposed policies (Shelby County, no date; County of Santa Clara Board of Supervisors, 2011; Curran et al., 2012).

- Despite an absence of provisions for paid maternity and parental leave in federal law, some states are introducing these provisions. In 2018, California's Parental Leave Act mandated maternity and parental leave for all new parents (including adoptive and fostering parents), six weeks unpaid and most mothers guaranteed a return to their job after maternity leave. Although some employees may be eligible for partial pay if enrolled in state disability insurance programmes, the law does not guarantee any pay (Tucker, 2018a; personal communication, 2018). New Jersey, New York and Rhode Island have similar maternity/parental laws in force and Washington state and Washington, DC laws on this will come into force in 2020 (New York State, 2018; Tucker, 2018a, 2018b).

- The number of children taken into foster care varies across states and is poorly explained by risk-factors know to predict abuse and neglect (Edwards, 2016a). So too does the type of foster care they are in with some states placing a much higher proportion with family members varying from $4 \%$ in Kentucky to $48 \%$ in Arizona. The proportion in group homes/institutions varies from $3 \%$ in Louisiana to $29 \%$ in Colorado. State policy regimes play a strong role in explaining these differences. Children are far less likely to be taken into foster care in states that have more extensive and generous welfare programmes (i.e. SNAP, TANF, Medicaid enrolment and TANF benefits) and less punitive criminal justice systems (Edwards, 2016a, $2016 \mathrm{~b}$ ). States with the highest proportions of children in care are reported as lowa, Minnesota, North and South Dakota, Nebraska, Oklahoma, Oregon, Rhode Island, West Virginia and Wyoming. Policy makers reportedly prefer interventions that align with their moral values, so states where conservative family values are strong and where abuse and neglect are seen as due to parental failings are likely to have more children in care (Edwards, 2016b).

- Twenty-eight states with Title IV-E waivers have demonstration projects that include wellbeing outcomes (See Table 5). Illinois and Indiana have reported improvements in FCHW associated with demonstration projects. Parents on parenting skills courses in Illinois, for example, substantially improved their parenting competencies. However, this does not tackle the structural inequalities that are the root causes of the problems poor families face. Furthermore, that Title-IV Wavier funding will not continue beyond September 2019 (Stoltzfus, 2017).

Table 5: Wellbeing outcomes of waiver demonstrations, USA

\begin{tabular}{|l|l|}
\hline Outcome & State \\
\hline Transition to adulthood & Arkansas, California \\
\hline $\begin{array}{l}\text { Child development, } \\
\text { behavioural functioning }\end{array}$ & $\begin{array}{l}\text { Colorado, District of Columbia, Florida, Hawaii, Illinois, Indiana, Kentucky, } \\
\text { Maine, Maryland, Massachusetts, Michigan, Nebraska, New York, } \\
\text { Oklahoma, Oregon, Pennsylvania, Tennessee, Texas, Utah, Washington, } \\
\text { Wisconsin, West Virginia }\end{array}$ \\
\hline Use of congregate care & $\begin{array}{l}\text { Arizona, California, Colorado, Indiana, Maryland, Massachusetts, } \\
\text { Pennsylvania, West Virginia }\end{array}$ \\
\hline $\begin{array}{l}\text { Caregiver } \\
\text { capacity/functioning }\end{array}$ & $\begin{array}{l}\text { Colorado, District of Columbia, Florida, Illinois, Kentucky, Maine, Michigan, } \\
\text { Nevada, Oklahoma, Oregon, Pennsylvania, Tennessee, West Virginia }\end{array}$ \\
\hline Placement with siblings & California, Indiana \\
\hline
\end{tabular}

Source: James Bell Associates, 2016.

\section{Comparing FCHW policy in the USA and in other countries}

As discussed in Section 4, there is evidence of limited policy focus and spending in this area. Despite some FCHW policy, it has not moved to providing universal services for all children, to policies intended to give every child the opportunity for the best possible start in life or become an investment state as in many other high-income countries. Table 6 summarises the evidence on what the USA does compared to other countries in relation to FCHW policy. 
Table 6: Features and differences in FCHW policy in the USA relative to other countries

\begin{tabular}{|c|c|c|}
\hline Policy Area & What the USA Does & What Other Countries Do \\
\hline Family benefits & $\begin{array}{l}\text { Means test cash benefits, EITC, } \\
\text { SNAP, Medicare; spend } 0.7 \% \text { of GDP } \\
\text { on family benefits. }\end{array}$ & $\begin{array}{l}\text { The OECD average spend on family benefits } \\
\text { is } 2.1 \% \text { of GDP. Only Turkey and Mexico } \\
\text { spend less than the USA. }\end{array}$ \\
\hline Healthcare & $\begin{array}{l}\text { Means tested with poorest having } \\
\text { Medicaid and low to middle-income } \\
\text { families getting subsidies. }\end{array}$ & $\begin{array}{l}51 \text { countries provide universal healthcare. } \\
\text { Columbia, India, Korea, Mexico and Turkey } \\
\text { are transitioning to universal coverage. } \\
\text { Transition examples are South Africa and } \\
\text { Rwanda where universal coverage is limited } \\
\text { to basic care. }\end{array}$ \\
\hline Parental leave & $\begin{array}{l}14 \text { weeks unpaid leave for mothers } \\
\text { working in firms with at least } 50 \\
\text { employees. }\end{array}$ & $\begin{array}{l}\text { Other OECD countries provide a minimum of } \\
14 \text { weeks paid leave. } 31 \text { countries give an } \\
\text { entitlement to paid paternity leave. An } \\
\text { example is Australia, which moved from } \\
\text { unpaid to paid universal maternity leave in } \\
\text { the } 2000 \text { s. }\end{array}$ \\
\hline ECEC & $\begin{array}{l}\text { Largely delivered and funded in the } \\
\text { private sector with limited funding for } \\
\text { children from poorest families. }\end{array}$ & $\begin{array}{l}\text { In OECD countries subsidised with universal } \\
\text { entitlement to at least one year of ECEC. }\end{array}$ \\
\hline $\begin{array}{l}\text { Vulnerable and } \\
\text { at-risk children } \\
\text { and families }\end{array}$ & $\begin{array}{l}\text { Main emphasis on taking children into } \\
\text { care although with a shift towards } \\
\text { developing preventative services. }\end{array}$ & Preventative services and child centred. \\
\hline $\begin{array}{l}\text { Ratification of } \\
\text { the CRC }\end{array}$ & $\begin{array}{l}\text { The USA has not ratified the treaty } \\
\text { and UNICEF does not work in the } \\
\text { USA. }\end{array}$ & $\begin{array}{l}\text { All UN member states with the exception of } \\
\text { the USA have ratified the treaty. UNICEF } \\
\text { actively promotes FCHW and children's } \\
\text { rights in } 190 \text { countries. An intermediate step } \\
\text { could be to ratify the convention with } \\
\text { reservations, which has been done in the } \\
\text { majority of countries that have ratified the } \\
\text { CRC. }\end{array}$ \\
\hline
\end{tabular}

There are differences in the organisation of social safety nets. Poorer than expected performance in child mortality in the USA, raised earlier, has been attributed to weak social safety nets, social inequalities that affect maternal, child and family health, and deprived social environments for many children (Chung and Muntaner, 2008; Howard, 2018a). Poor parents are seen to be responsible for these situations (Cahn and June, 2010; Palley and Shdaimah, 2014; Mitchell, Pavetti and Huang, 2018). As raised in Section 4, the USA is the only country that does not provide paid parental leave, spends less on family benefits than almost every other OECD country and has concentrated on providing support to the poorest and most vulnerable children and targeting services to children at risk, providing limited support to working parents with strict eligibility criteria for family benefits. By contrast, in most OECD countries the benefits system enables lone parents to make choices between work and care and, in some, to take paid maternity leave for the first year (Garfinkela and Zilanawalab, 2015). Other OECD countries provide at least 14 weeks of paid maternity leave and may also provide paid paternity and parental leave. Many high-income countries have non-time limited and more generous benefits for all non-working families, recognising the importance of investing in all children and ensuring they have the best possible start in life. In this, the UK is instructive, its policy of making work pay was influenced by USA policy. However, unlike the USA it also introduced policies to raise income support and to invest in children. Consequently, poverty levels declined for all children in the UK, while in the USA those living in a household without a working parent moved into deeper poverty (Waldfogel, 2010).

In terms of education, the USA provides limited support for ECEC for children from poor homes, and most families have to purchase ECEC from private providers. In other OECD countries, all children are entitled to at least one-year free ECEC. In a number of countries, enrolment rates for four-years olds are approaching 100\% with the OECD average being $80 \%$ compared to $58 \%$ in the USA (Gambaro, Stewart and Waldfogel, 2015b). 
In terms of support for at-risk children and their families, the USA continues to see the preferable option as taking children into care and finding them adoptive parents rather than keeping children with their families. It has not made the same shift to prevention of child abuse and neglect as has been made in other high-income countries (Brown, 2016; Finck et al., 2016). With a funding bias towards foster care and adoption services, a far higher proportion of children in the USA are adopted than in any other country in the world and a very high proportion of these are American children (Department of Economic and Social Affairs Population Division, 2009). In Europe it is generally recognised that children are better cared for by their parents and only if that is not possible taking them into care. The funding system is biased towards prevention and reunification (Jordan and Connelly, 2016; Stoltzfus, 2017). This is, however, noted to be an area where policy shifts are taking place towards preventive services and more concern about the wellbeing of children in the welfare system, placing them with other members of their family or adoption if they cannot return to their own parents.

As noted earlier, normative values vary between the USA and many other countries, with its normative and legal framework underpinned by principles of individual liberty and autonomy, compared to the stronger support for collective responsibility and state roles in other countries. This affects policy choices. For example, the USA remains the only UN member country that has not ratified the CRC, despite evidence of its role in FCHW policy change, and there is no evidence that international agencies such as UNICEF are active in promoting FCHW and child rights in the USA, as they are in 190 other countries globally (UNICEF, no date c). The USA played a major role in drafting the treaty so it would be in line with its values and voted for its adoption (Davidson, 2014). President Clinton signed the treaty when in office but never submitted it to the Senate for ratification because it would not have secured the required two-thirds majority.

\section{Challenges and opportunities in the USA}

In this section, we summarise the opportunities and challenges for greater policy recognition of FCHW in the USA. The main question is why the USA has not moved to promoting FCHW as in other countries given that it faces similar problems to other high-income countries and comparable policy options are available. As Children Now asks:

Why, with near consensus in our country on creating equal opportunity for all children, regardless of race or income, do kids fare so poorly in public policymaking? Despite the existence of thousands of groups fighting for numerous child-related causes, the lack of a powerful, unified advocacy effort has allowed other interests to continually supersede kids in priority and resources. The children's base is fractured and kids are losing out (Children Now, no date).

Challenges to raising policy recognition of FCHW in the USA

In the issue stream, the framing of problems means that children as a whole are not seen as an issue, making it difficult to increase policy recognition that puts the best interest of all children first (Palley and Shdaimah, 2014). Problems are generally framed as ones of specific groups of children, for example, 'vulnerable children', 'at-risk children', 'children in foster care', 'ethnic minority children' and 'migrant children'. Childcare needs in the USA, for example, are framed in several different ways: as a need for care because they have employed mothers; as a need to break the intergenerational cycle of poverty by providing ECEC for children from poorest homes; as a need for poor children to have ECEC so they don't start school 'behind' their peers; and as a need for quality ECEC. There is no overall advocacy for quality ECEC for all children.

Social norms and ideas of individual liberty and non-interference by the state in families overtake evidence, so that only some poor families are seen as 'deserving' of welfare support (Palley and Shdaimah, 2014; Tsai and Chen, 2017; Connelly and Rosinsky, 2018a, 2018b). Powerful socially and economic conservative groups have thus thwarted or circumscribed attempts to introduce more progressive legislation and policies (Palley and Shdaimah, 2014). Over the last 20 years, state support for single parent families has moved from enhancing economic security to deterring dependency, with moral values taking precedence in determining policy over the best interest of 
the child, and the poorest families being driven into even deeper poverty (Palley and Shdaimah, 2014; Garfinkela and Zilanawalab, 2015; Hoynes and Schanzenbach, 2018).

The USA is the only UN member state that has not domesticated the CRC, and those who advocate for child rights face opposition from Republicans who argue that it undermines national and parental sovereignty (Rothschild, 2007). In California, Senator Richard Pan and his supporters had to recast children's rights as parental rights to access services to get a Child Rights Bill accepted. Pro-family ideologies that stress the importance of parental rights and the $14^{\mathrm{th}}$ amendment to the Constitution make it difficult to get policies for children and families approved (Danziger and Waldfogel, 2000; Gadsden, Ford and Breiner, 2016).

Children as a demographic are unable to represent their interests directly, having neither direct representation in government as voters do nor funding for a lobby to represent their interests as large corporations can (Nayowith, 2010; Palley and Shdaimah, 2014). Parents may not have the time and resources to advocate for children, especially those that are most marginalised or with greatest need. They are reported to lack key information, such as how to identify good quality ECEC provision (Workman et al., no date; Blau, 2002; Schaefer et al, 2012). There are persistent socioeconomic, racial and immigrant status inequalities. Gaps between African American and Hispanic children and white native children have not narrowed since the 1980s (Land, 2014a). Children of immigrants are a large share of the young child population, many live-in low-income families with parents with low educational attainment, limited English ability, a greater likelihood of poverty but lower benefit use (Child Trends, 2014). Children and their parents thus rely on NGOs to voice concerns. While there are a large number of child advocacy groups, they have diverse interests and are not co-ordinated in a combined voice advocating for children nationally (Nayowith, 2010; Palley and Shdaimah, 2014; Annie E Cassey Foundation, 2017).

In relation to policy content, advocacy groups argue for different policy options and priorities depending on what lens they view children through and the political, economic and social constraints they face (Palley and Shdaimah, 2014). They are also constrained by political and social beliefs on individual family responsibilities and non-interference by the state, by the government desire to reduce public spending and by limited resources and competing demands for services for families and children (Palley and Shdaimah, 2014). This often puts advocates in a position in defending existing policies against encroachment, rather than advocating for innovations.

FCHW is reported not to be a funding priority at federal or state level (McGowan, 2014; AACF, 2018; Children Now, 2018; The Children's Defence Fund Cailfornia, 2018; The Children's Partnership and The Children's Defence Fund California, 2018). The funding system for child welfare, which is complex and burdensome, constrains the policy options that are seen as feasible with welfare services generally underfunded and pronounced funding variability across states (Radel, 2005; Pecora et al., 2006; CSSP, 2009; Jordan and Connelly, 2016). The previous sections have pointed to concerns about inflexible funding, discouraging innovation, emphasis on downstream approaches, not aligned to changes in child welfare, and driven by processes rather than outcomes (Casey Family Programmes, 2010; Annie E Casey Foundation, 2013b; Currie and Reichman, 2015; Jordan and Connelly, 2016). There is a shortage of funding and skilled staff to support innovative policy options (McGowan, 2014). While Title IV-E waivers give states some flexibility, funding is time limited, the cap is problematic and funding ends after 2019 (James Bell Associates, 2016; Jordan and Connelly, 2016; Stoltzfus, 2017).

The federal system combined with limited funding for innovative practice limits the potential for disseminating information on innovative best practice and scaling it up to national level. The strong market orientation also limits options for service delivery, limiting consideration of public sector policy options that support collective measures or a child rights approach.

While there has been an increase in the availability of data measuring FCHW at federal level, significant gaps remain at state level (Curran et al., 2012). Advocacy groups lack good quality data to back their demands for a shift to FCHW policy. However, new national maps, detailed to the census tract level have recently been published, illustrating children's outcomes in adulthood by neighbourhood (Badger and Bui, 2018). Except for the health sector, states generally lack data 
disaggregated by age, gender, socioeconomic status, age, gender, ethnicity or migration status at state or district levels to plan or assess interventions. Data on how children feel about their lives are not routinely collected. While publication of comparative data is used for advocacy internationally and for states in the USA, there is less evidence that policy makers use data in shaping policy.

In the political stream, the weak or absent political discussion about prioritising children's needs suggests limited political will and few political champions to push FCHW up the political agenda (Palley and Shdaimah, 2014; Annie E Cassey Foundation, 2017). There are some exceptions to this. President Clinton signed the CRC and President Obama supported campaigns for ECEC for three- and four-year olds (Palley and Shdaimah, 2014). In 2015 Obama honoured twelve extraordinary individuals who supported working families with family-friendly policies that encourage workplace flexibility (Jarrett, 2015). State legislatures also have champions for children (Jordan and Connelly, 2016). Frequent changes in government at federal and state level weaken policy consistency and stability (Fitzpatrick and Kostina-Ritchey, 2014). Progressive policies introduced under one government can be cut back or abandoned under subsequent ones. Presidents can find it difficult to get legislation passed when the majority party in Congress is different from their own as happened under both the Clinton and Obama administrations.

\section{Opportunities raising policy recognition of FCHW in the USA}

Policy windows and agenda setting opportunities provide openings for moving FCHW up the policy agenda. This requires that FCHW is seen as a social problem/issue requiring government action, that there are technically feasible solutions, consistent with dominant values and acceptable to the electorate and that there is political will to implement them. A convergence of the streams enables forces to combine to tap windows of opportunity for policy change (Loewenson and Masotya, 2018).

In the issue stream, the evidence in Section 4 suggests that some FCHW policies and values are out of sync with public opinion. Poll data suggest that the American public care about children, support equal opportunities and are willing to spend more money on children, especially for health, ECEC and social protection (Waldfogel, 2010; American Humane Association, 2015; Udall, 2015; Annie E Casey Foundation, 2016; Cox and Jones, 2017). Americans generally support equal opportunities for all children and are prepared to pay higher taxes to fund ECEC (Workman et al., no date; Annie E Casey Foundation, 2016; Cox and Jones, 2017). The public agrees that all children should have the opportunity for quality ECEC, with $80 \%$ favouring free provision for all children (Workman et al., no date; Magnuson and Waldfogel, 2014; Annie E Casey Foundation, 2016; Cox and Jones, 2017). Employers were also reported to want an increase in publicly funded ECEC (Waldfogel, 2006, 2010). As good economic sense, it is estimated that the return on investment for ECEC for children from low income homes is between 7\% and 10\% (Folbre, 2008; Trostel, 2013; Bishop-Josef, Schaefer and Watson, 2014). Providing parents with information on how to recognise good quality care enables them to make better choices.

These policy issues can be influenced by media (and social media) attention about child fatalities, class action suits, media concerns on issues such as child obesity and adolescent harmful drug use, and publicity on how the USA or individual states are doing comparatively on indicators and indexes of FCHW. This can influence the framing of priorities and options for children and families (Jordan and Connelly, 2016). Social networks and alliances and policy briefs and lobbying by advocacy groups also have the potential to influence policy focus and options (Palley and Shdaimah, 2014).

From evidence in Section 4, opportunities for promoting FCHW appear to have opened up and progress has been made when the Democrat party is in power at federal or state levels (Kamerman and Kahn, 2001). Democrat-led states have generally led the way in legislating for paid parental leave and in providing state-funded ECEC. While at federal level areas of progress may currently be under threat, there is an opportunity to work at state levels to demonstrate and collect evidence on good practice to support future policy initiatives and sustain good practice.

In relation to policy options, there are technical solutions/policies options available for shifting to FCHW, as discussed in Sections 3 and 4 with technical solutions to support policy framing and implementation. States, NGOs and foundations are supporting and carrying out innovations that often bring together the public, private and voluntary sectors. While the federal system is a challenge 
to nationwide policy adoption and federal funding a lever to policy choice, a federal system also provides potential openings for progressive states to introduce policies to promote FCHW.

There is increasing recognition that children at risk are best managed in their community rather than being taken into care, backed by evidence-informed programmes that have been shown to work, as described in Section 3.4. The Family Services Prevention Act 2018 provides limited funding for preventive services, an indication that politicians are also more open to community interventions. The recent media on child separation in undocumented migrants suggests that there is a dominant view that the best place for children is with their families.

As an option for improving co-ordination between departments and agencies at federal level, the Government Accountability Office has recommended identifying child wellbeing as a cross-agency priority. This would ensure a co-ordinated approach at federal level to improve policy implementation and to draw attention to federal efforts to improve child wellbeing (Government Accountability Office, 2017).

For political actors, the evidence suggests a number of arguments for getting FCHW on the policy agenda. One is in terms of the costs to households and the economy of poor investments in this area. The second is making the economic case for collective investment in FCHW, with a focus on children, showing the positive socioeconomic impact of such investment, especially those directed towards children (Danziger and Waldfogel, 2000; Waldfogel, 2010). Equally the concern with making more effective, relevant and equitable use of government expenditure, such as in the mismatch between health spending and health outcomes, can focus attention on opportunities for adopting learning on better performing systems to improve value for money and reduce cost escalation (Training and Research Support Centre, 2014).

Political actors in states present a potential resource in policy areas. For example, a number of states have legislated for paid maternity leave, and in his 2018 budget President Trump proposed six weeks maternity leave at $66 \%$ wage replacement (Brainerd, 2017). The ACA was implemented under the Obama administration. These laws provide an opening for political debate and shift of norms on universal or solidarity policies, reinforcing some of the findings from public opinion polls, raised earlier, on areas for wider public and state intervention (Waldfogel, 2006, 2010).

Several countries have used Child Impact Statements as a tool for assessing the potential impact of policy, provision, legislation etc on children, in response to doing comparatively poorly on measures of child wellbeing. This suggests that more liberal states and counties may be open to introducing such statements and having a more rights-based approach for children.

These potential opportunities for moving FCHW up the policy agenda in the USA resonate with international experience, shown in Table 7 overleaf.

Organisations that advocate for FCHW can help build connections between policy issues, content and political actors, profile policy options and strengthen dialogue across public, private and voluntary agencies on ways of strengthening services and innovating on FCHW. The Robert Wood Johnston Foundation with Ashoka, for example, has launched the children's wellbeing network to bring together innovative leaders across the USA to promote a culture of wellbeing for children (RWJF and Changemakers, no date). The Annie E Cassey Foundation similarly advocates for child wellbeing, invests in projects to improve FCHW and brings together public, private and voluntary sectors to deliver innovative, evidenced-based programmes ((Annie E Casey Foundation, no date). 
Table 7: Windows of opportunity for increased recognition of FCHW in the USA

\begin{tabular}{|l|l|l|}
\hline Windows & Drivers (USA) & Drivers (international) \\
\hline $\begin{array}{l}\text { Paid } \\
\text { maternity/parental }\end{array}$ & $\begin{array}{l}\text { Increased number of dual workers } \\
\text { households } \\
\text { Research evidence on attachment } \\
\text { and importance of early child } \\
\text { development } \\
\text { Support from political leaders }\end{array}$ & $\begin{array}{l}\text { Increased number of dual workers } \\
\text { households; Labour market shortages } \\
\text { Research evidence on attachment and } \\
\text { loss and importance of early child } \\
\text { development } \\
\text { Support from political leaders }\end{array}$ \\
\hline $\begin{array}{l}\text { Community services } \\
\text { for children at risk } \\
\text { and their families }\end{array}$ & $\begin{array}{l}\text { Media attention } \\
\text { Class action lawsuits } \\
\text { Political leadership } \\
\text { Impact evaluation on what works }\end{array}$ & $\begin{array}{l}\text { Media attention } \\
\text { Research evidence }\end{array}$ \\
\hline ECEC & $\begin{array}{l}\text { Supportive public opinion } \\
\text { Increased dual worker families and } \\
\text { single parent families } \\
\text { Research evidence on the benefits } \\
\text { to children of ECEC }\end{array}$ & $\begin{array}{l}\text { Adoption of the CRC } \\
\text { Increased dual worker families and single } \\
\text { parent families. } \\
\text { Support from political leaders } \\
\text { Research evidence on benefits to children } \\
\text { of ECEC }\end{array}$ \\
\hline $\begin{array}{l}\text { Child impact } \\
\text { statements -i.e. on } \\
\text { the potential impact } \\
\text { of policies on } \\
\text { children }\end{array}$ & $\begin{array}{l}\text { Public support for improving child } \\
\text { wellbeing } \\
\text { Poor performance on key indicators } \\
\text { of FCHW putting pressure on } \\
\text { politicians to do better, } \\
\text { Political leaders supporting }\end{array}$ & $\begin{array}{l}\text { Adoption of the CRC encourages } \\
\text { countries to use child impact statements, } \\
\text { which countries have started to do }\end{array}$ \\
\hline $\begin{array}{l}\text { A co-ordinated } \\
\text { approach at federal } \\
\text { level to the } \\
\text { implementation of } \\
\text { children's policy }\end{array}$ & $\begin{array}{l}\text { Government Accountability Office } \\
\text { Office of Management and Budget } \\
\text { Experts put in place to improve co- } \\
\text { ordination of services }\end{array}$ & $\begin{array}{l}\text { Commitment by political leaders to joined } \\
\text { up government }\end{array}$ \\
\hline $\begin{array}{l}\text { Effective, relevant } \\
\text { equitable use of } \\
\text { government health } \\
\text { expenditure }\end{array}$ & $\begin{array}{l}\text { Elimination of waste in government } \\
\text { spending }\end{array}$ & $\begin{array}{l}\text { Strong commitment to collective } \\
\text { responsibility for healthcare }\end{array}$ \\
\hline
\end{tabular}

\section{Discussion}

\subsection{Contexts and drivers of policy recognition of FCHW}

The evidence in this paper has pointed to some of the contexts for FCHW policy recognition and change in countries internationally, including:

- Social and demographic changes in countries, such as declines in family size, demographic transition in low- and middle-income countries, an increase in lone parent and fragile families, an increase in dual earner families, labour market demands for skilled labour, and concerns to reduce child poverty, address socioeconomic inequalities and ensure the wellbeing of children at risk, all calling for new ways of addressing FCHW.

- Political economy values, beliefs and norms and an ideological commitment to inclusion and collective responsibility for FCHW, such as is reflected in public support for welfare systems in Europe and other OECD countries or a religious /philosophical commitment to promoting the wellbeing of citizens, such as in Bhutan.

- At international level, the CRC and engagement on its ratification and domestication; with international institutions and partners promoting rights-based approaches for FCHW, backed by evidence for peer review across countries, international and regional support for and sharing evidence on good practice in $\mathrm{FCHW}$, and incentives from international aid funding.

- Major social tipping points (crises and political transitions), such as changes in government, and post-conflict or post-dictatorship nation building and reconstruction, with shared support for social protection to help address risk, vulnerability and chronic poverty and improvement of the wellbeing of children. 
Drawing on the analytical framework (Loewenson and Masotya, 2018), there was evidence of domestic drivers of policy change. Changes of government towards partiers and political actors committed to improving child wellbeing on electoral platforms have encouraged new policy dialogue and options. States provide important financial levers to incentivise policy change, whether through funding research or pilot interventions; while federal governments may put barriers on innovation, individual states may be able to use political and financial levers and build local political champions for FCHW. Evaluation of changes in practice at local and state levels can provide evidence, confidence and support for policy shifts at higher levels.

Public norms, opinion and media play important roles. Opinion polls can indicate where public opinion has shifted and inform policy and political actors, as was observed in the USA. International institutions such as UNICEF have brought new evidence and paradigms to national NGOs and states, as reflected in the CRC. So too have academic researchers and research by policy think tanks and international institutions to provide a better understanding of FCHW problems and their impact, as well as evidence on which to base policy options. Indicators and indices measuring FCHW have been a powerful driver pointing out the problems and progress in implementing and achieving outcomes from FCHW interventions, comparing progress across countries and regions and for different groups within countries. Contexts are also rapidly changing, with new national and global tensions between populism and multiculturalism, and liberal versus conservative/isolationist values.

The paper provides evidence of how these factors act together, and of the importance of 'policy entrepreneurs' who cross streams, bringing evidence from those affected to policy and political actors, bringing policy options to political streams, and strengthening the links across key constituencies to enable a convergence of ideas and interests for policy change. At the same time, the paper also provides evidence of how positive policy change can be reversed, and that these same domestic alliances, international actors and factors may be needed to sustain and defend positive policy when contexts become less favourable.

\subsection{Implications for country selection for the case studies}

Discussions within TARSC and University of Aberdeen team have identified that country selection should be informed by two key criteria: (1) countries that resonate with the USA context, challenges and opportunities and (2) countries that have made a policy shift to FCHW. From the evidence in this paper, the USA context suggests that it may be useful to include among the countries considered those with comparable contextual features of:

- Federal systems of government co-ordinating delivery of FCHW policies, programmes and services and/or opportunities for administration and innovation of federal policy and programming at national, state and local levels.

- Evidence of social inequality, in terms of child poverty, economic inequalities and disadvantaged groups (on grounds of social features such as ethnicity, race, migration status), and/or countries that have shown improvements in social inequality following strengthened $\mathrm{FCHW}$ policies, programmes and investments.

- Involvement of private and voluntary sectors in services, with reduced state intervention.

- Policy concerns and features that connect with public opinion, policy opportunities and entry points in the USA, including maternity/parental leave, family benefits and support; ECEC; community services for children at risk and their families; management of child obesity and adolescent harmful drug use; improving effective coverage of early preventive and care services and healthcare coverage; and improved service value for money and co-ordination.

The evidence on international experiences suggests that for countries that have shown a positive trend in introducing policies that relate to $\mathrm{FCHW}$, the countries could include those that have made policy change in areas where there may be opportunities for policy recognition in the USA, but that also reflect positive changes in FCHW policy internationally, viz:

- Reduction of child poverty and of social inequalities and integration of migrant children.

- Introduction of social protection and safety nets for children and legal entitlements to maternity and parental leave and flexible working for parents. 
- Entitlement of at least one year's free quality ECEC and measures for improved educational outcomes for all children.

- Preventive policies and community-based programmes to reduce the risk of children being taken into care and improve options for them to be reunited with their families.

- Improved health promotive, preventive and care coverage, including for adolescents.

- Co-ordination of FCHW policy delivery, services and programmes at national and devolved levels, with incentives for and use of local pilots and programmes for learning on innovation.

- Strengthened community information, systems, networks and advocacy.

- Investment in FCHW data, including subjective and disaggregated data used by affected groups, technical and political actors for advocacy, decision making, planning, progress monitoring and review, including options for national review, e.g. child impact statements. 


\section{References}

1. Abbott P (2013) 'Promoting children's rights under EDPRS 1 and priorities for EDPRS 2', UNICEF: Rwanda.

2. Abbott P and Sapsford F (2012) 'Legal and policy framework for children's rights in Rwanda', Rwandan public policy observatory report. Kigali. Available at: http://opendocs.ids.ac.uk/opendocs/handle/123456789/9659.

3. Abbott P, Sapsford R and Binagwaho A (2017) 'Learning from success: How Rwanda achieved the Millennium Development Goals for health', World development. Pergamon 92:103-116.

4. Aber JL et al. (2010) 'Using child indicators to influence policy: QA comparative case study' in Kamerman SB, Phipps, S and Ben-Arieh A (eds) From child welfare to child wellbeing: An international perspective on knowledge in the service of policy making. Springer: New York, Heidelberg, Dordrecht and London.

5. Abrahamsen R (2000) Disciplining democracy: Development discourse and good governance in Africa. Zed Books: London.

6. Adamson, P. (2013) 'Child wellbeing in rich countries: A comparative overview: Innocenti report Card 11', Florence. Available at: https://www.unicef-irc.org/publications/pdf/rc11_eng.pdf.

7. Adler A (2009) 'Gross national happiness in Bhutan: A living example of an alternative approach to progress', Social Impact Research Experience (SIRE). Available at: https://repository.upenn.edu/cgi/viewcontent.cgi?article=1003\&context=sire.

8. Adler A (2016) Teaching wellbeing increases academic performance: Evidence from Bhutan, Mexico, and Peru. University of Pennsylvania: Philadelphia. Available at: https://repository.upenn.edu/cgi/viewcontent.cgi?article=3358\&context=edissertations.

9. Adler A and Seligman M (2016) 'Using wellbeing for public policy: Theory, measurement, and recommendations', International journal of wellbeing, 6:1-35.

10. Aldgate J (2010) 'Child wellbeing: Understanding children's lives at home, school and in the community' in McAuley C and Rose W (eds) Child wellbeing: Understanding children's lives. Jessica Kingsley: London and Philadelphia.

11. Alter A and Meyers J (2016) 'Ensuring the best start for Connecticut's children: Aligning policy with science', Farmington. Available at: https://www.chdi.org/index.php/publications/reports/policy-briefensuring-best-start-connecticuts-children-aligning-policy-science.

12. American Humane Association (2015) The state of America's children. American Humane Association: Washington, DC.

13. Annie E Casey Foundation (2013a) 'Lessons learned from making connections', Annie E Casey Foundation: Baltimore.

14. Annie E Casey Foundation (2013b) 'When child welfare works: A working paper', Annie E Casey Foundation: Baltimore.

15. Annie E Casey Foundation (2015) 'Every kid needs a family', Annie E Casey Foundation: Baltimore.

16. Annie E Casey Foundation (2016) '2016 Kids COUNT data book', Annie E Casey Foundation: Baltimore:

17. Annie E Casey Foundation (2017) '2017 Kids COUNT data ook', Annie E Casey Foundation: Baltimore.

18. Annie E Casey Foundation (2018a) '2018 Kids COUNT data book: State trends in child wellbeing', Annie E Casey Foundation: Baltimore.

19. Annie E Casey Foundation (2018b) 'Kids COUNT data centre', Data Centre. Annie E Casey Foundation: Baltimore.

20. Annie E Casey Foundation (no date) Web page. Avalable at: https://www.aecf.org/about/.

21. Anon (2018a) 'Family first: A "Reform" that Isn't', Child welfare monitor, 13 Febuary.

22. Anon (2018b) 'The Family First Act: A bad bill that won't go away', Child welfare monitor, 7 February.

23. Anyabwile T, Kaye, PE and Harrell J (2003) 'Promoting better family health: Recomendations for state policy'. Washington, DC.

24. Arkansas Advocates for Children and Families (AACF) (2018) Health and wealth in Arkansas: How our history of policy choices connected them and what we can do about it. Springdale: Little Rock. available at: http://www.aradvocates.org/wp-content/uploads/AACFhealth.wealth.webfinal.rev_.2.6.4.18.pdf

25. Badger $E$ and Bui Q (2018) 'Detailed new national maps show how neighbourhoods shape children 
for life', The New York Times. Available at: https://www.nytimes.com/2018/10/01/upshot/mapsneighborhoods-shape-child-poverty.html.

26. Baker M (2006) Restructuring family policies : Convergences and divergences. University of Toronto Press: Toronto.

27. Banati $P$ and Alexander G (2012) 'Structural determinants of child wellbeing, An expert consultation hosted by the UNICEF Office of Research', 22-23 June 2012. Florence.

28. Bartholet E (2011) 'Ratification by the United States of the convention on the rights of the child: Pros and cons from a child's rights perspective', Annals of the American academy of political and social science 633(1).

29. Baxter J et al. (2007) 'Mothers and fathers with young children: Paid employment, caring and wellbeing'. Canberra. Available at:

https://www.dss.gov.au/sites/default/files/documents/05_2012/sprp30.pdf.

30. Ben-Arieh A (2010a) 'Developing Indicators for child wellbeing in a changing context' in McAuley C and Wendey R (eds) Child wellbeing: Understanding children's lives. Jessica Kingsley: London and Philadelphia.

31. Ben-Arieh A (2010b) 'From child welfare to children wellbeing: The child indicators perspective' in Kamerman SB, Phipps S and Ben-Arieh A (eds) From child welfare to child wellbeing: An international perspective on knowledge in the service of policy making. Springer: Dordrecht, Heidelberg, London and New York, 9-22. Available at: https://link.springer.com/content/pdf/10.1007\%2F978-90-481-3377-2.pdf.

32. Ben-Arieh A (2014) 'Social policy and the changing concept of child wellbeing. The role of international studies and children as active participants', Zeitschrift für Pädagogik 60(4)569-81.

33. Ben-Arieh A et al. (2014) 'Multifaceted concept of child wellbeing' in Ben-Arieh A et al. (eds) Handbook of child wellbeing: Theories, methods and policies in global perspective. Springer: Dordrecht. Available at: https://link.springer.com/content/pdf/10.1007\%2F978-90-481-90638 134.pdf.

34. Ben-Arieh A and Goerge RM (2006) 'Measuring and monitoring children's wellbeing: The policy process' in Ben-Arieh A and Goerge RM (eds) Indicators of children's wellbeing: Understanding their role, usage and policy influence. Springer: Dordrecht, 21-30. Available at: https://link.springer.com/content/pdf/10.1007\%2F1-4020-4242-6.pdf.

35. Berger LM and Font SA (2015) 'The role of the family and family-centered programmes and policies', The future of children 25(1)155-76.

36. Bhardwaj S, Sambu W and Jamieson $L$ (2017) 'Setting an ambitious agenda for children: The Sustainable Development Goals' in Jamieson L, Berry L and Lake L (eds) South African child guage. The Children's Institute, University of Cape Town: Cape Town. Available at: http://www.ci.uct.ac.za/sites/default/files/image_tool/images/367/Child_Gauge/South_African_Child_ Gauge_2017/Child_Gauge_2017_lowres.pdf.

37. Bishop-Josef S et al. (2014) 'Strengthening Kentucky businesses through investments in early care and education', Washington, DC. Available at: http://www.prichardcommittee.org/wpcontent/uploads/2014/03/KY-early-ed-economic-analysis-report.pdf.

38. Bishop-Josef S, Schaefer S and Watson S (2014) 'Strengthening Pennsylvania businesses through investments in pre-kindergarten', America's edge, Washington, DC. Available at: http://www.prekforpa.org/wp-content/uploads/2014/04/PA-Multiplier-Report-4-25-14.pdf.

39. Bitler M, Hoynes H and Kuka E (2014) 'Child poverty and the great recession in the United States', UNICEF Office of Research-Innocenti: Florence. Available at: https://www.unicefirc.org/publications/pdf/iwp_2014_11.pdf.

40. Blau D (2002) 'Rethinking U.S. child care policy', Issues in Science and Technology, XVIII(2). Available at: http://issues.org/18-2/blau/.

41. Blue Ribbon Commission (2016) 'Improving the wellbeing of Washington state's children, youth and families', Olympia, Washington. Available at: https://www.governor.wa.gov/sites/default/files/documents/BRCCF_FinalReport.pdf.

42. Bogenschneider K (2011) 'Family policy: Why we need it and how to communicate its value', New York. Available at: https://www.un.org/esa/socdev/family/docs/egm11/Bogenschneider-paper.pdf.

43. Bradshaw J et al. (2010) 'The subjective wellbeing of children' in McAuley C, Rose W and Pugh G (eds) Child wellbeing: Understanding children's lives. Jessica Kingsley: London,181-204. Available at: http://oro.open.ac.uk/id/eprint/20984. 
44. Bradshaw J et al. (2013) 'Children's subjective wellbeing in rich countries', Florence. Available at: http://www.unicef-irc.org/publications/686.

45. Bradshaw J (2015) 'Subjective wellbeing and social policy: Can nations make their children happier?' Child Indicators Research 8(1) 227-41

46. Bradshaw J and Rees G (2017) 'Exploring national variations in child subjective wellbeing', Children and youth services review, 80:3-14.

47. Brainerd J (2017) 'Paid family leave in the States', Legis Brief 25(31). Available at: http://www.ncsl.org/LinkClick.aspx?fileticket=krAvd-XY2OM\%3D\&tabid=31635\&portalid=1.

48. Brazier C (2017) 'Building the future: Children and the Sustainable Development Goals in rich countries', Florence. Available at: https://www.unicef-irc.org/publications/pdf/RC14_eng.pdf.

49. Brooks A.-M, Hanafin S and Langford S (2010) 'National reporting on child wellbeing: The state of the nation's children reports in the Republic of Ireland' in McAuley C and Rose W (eds) Child wellbeing: Understanding children's lives. Jessica Kingsley: London. Available at: https://www.jkp.com/uk/child-wellbeing-2.html/\%0D.

50. Brown TK (2016) 'How US welfare compares around the globe', BBC News. Available at: https://www.bbc.co.uk/news/world-us-canada-37159686

51. Bruch SK, Meyers MK and Cornick JC (2018) 'The consequencies of decentralisation: Inequality in saftey net provision in the post-welfare reform era', Social service review 92(1)3-35.

52. Bruckauf $Z$ (2015) 'The Philippines' in Daly M et al. (eds) Family and parenting support policy and provision in a global context. UNICEF Office of Research-Innocenti: Florence. Available at: https://www.unicef-irc.org/publications/pdf/01.

53. Bruyere E and Garbarino J (2010) 'The ecological perspective on the human rights of children' in Kamerman SB, Phipps S and Ben-Arieh A (eds) From child welfare to child wellbeing. Springer: Dordrecht, 137-54. Available at: https://link.springer.com/content/pdf/10.1007\%2F978-90-481-33772.pdf.

54. Burton P and Phipps S (2010) 'In children's voices', in Kamerman SB, Phipps S and Ben-Arieh A (eds) From child welfare to child wellbeing. Springer: Dordrecht, 217-28. Available at: https://link.springer.com/content/pdf/10.1007\%2F978-90-481-3377-2.pdf.

55. Cahn N and June C (2010) Red families v. blue families: Legal polarization and the creation of culture. Oxford University Press: New York. Available at: https://www.amazon.co.uk/Red-Families-vBlue-Polarization/dp/0195372174/ref=sr_1_1?ie=UTF8\&qid=1535625024\&sr=8$1 \&$ keywords $=$ red + states $+\mathrm{v}+$ blue + states.

56. Cahn N and June C (2014) Marriage markets: How inequality is remaking the American family. Oxford University Press: New York. Available at: https://www.amazon.co.uk/Marriage-MarketsInequality-Remaking-American/dp/0199916586/ref=sr_1_2?ie=UTF8\&qid=1535625752\&sr=82\&keywords=cahn+and+carbone.

57. Camfield L, Streuli N and Woodhead M (2008) Children's wellbeing in contexts of poverty: Approaches to research, monitoring and participation. University of Oxford, UK Available at: https://www.younglives.org.uk/sites/www.younglives.org.uk/files/YL-TN12-Camfield-ChildWellbeing.pdf.

58. Camilletti E (2018) 'Realizing an enabling environment for adolescent wellbeing : An inventory of laws and policies for adolescents in South Asia', Florence. Available at: https://www.unicefirc.org/publications/pdf/WP.

59. Carpenter B (2007) 'The impetus for family-centred early childhood intervention', Child care, health and development 33 (6) 664-669

60. Carter T P et al. (2006) 'Comprehensive statewide approach to improve youth outcomes: Experience of the New York state youth development team', Journal of public health management and practice : JPHMP (Suppl) S32-40. Available at: https://www.ncbi.nlm.nih.gov/pubmed/17035899.

61. Casey Family Programmes (2010) 'Ensuring safe, nurturing and permanent families for children: The need for Federal Finance Reform', Casey Family Programmes, Seattle.

62. Casey Family Programmes (2016) 'Strong families and safe children. How community resource centers are helping families in Gainesville', Washington, DC.

63. Cash SJ and Anderseon-Butcher D (2006) 'Support for young people and their families in the community in McAuley C, Pecora PJ and Rose W (eds) Enhancing the wellbeing of children and families through effective interventions: International evidence for practice. Jessica Kingsley: London and Philadelphia. 
64. Centre for Public Impact (2016) Chile Crece Contigo (CCC): Supporting early years development, Centre for Public Impact: Santiago, Available at: https://www.amazon.co.uk/Enhancing-Well-beingChildren-Effective-Interventions/dp/1843101165

65. Centre for the Study of Social Policy (2006) 'Places to watch: Promising practices to address racial disproportionality in child welfare', San Francisco.

66. Centre for the Study of Social Policy (2009) 'Policy matters: Setting and measuring benchmarks for state policies', Washington, DC.

67. Centre for the Study of Social Policy (2013) 'Raising the bar: Child welfare's shift toward wellbeing', San Francisco.

68. Chambers V and Booth $D$ (2012) 'Delivering maternal health: Why is Rwanda doing better than Malawi, Niger and Uganda', London. Available at: https://www.odi.org/sites/odi.org.uk/files/odiassets/publications-opinion-files/7696.pdf.

69. Child Heath and Development Institute of Connecticut (CHDI) (no date) Issue briefs, publications and issues briefs. Child Heath and Development Institute of Connecticut, Inc. Available at: https://www.chdi.org/publications/

70. Chief Secretary to the Treasury (2003) 'Every child matters', London. Available at: https://assets.publishing.service.gov.uk/government/uploads/system/uploads/attachment_data/file/27 2064/5860.pdf.

71. Child Trends (2014) 'Immigrant children: Indicators of child and youth wellbeing', Bethseda. Available at: https://www.childtrends.org/wp-content/uploads/2013/07/110_Immigrant_Children.pdf.

72. Child Welfare Information Gateway (2016) 'Major federal legislation concerned with child protection, child welfare, and adoption', Washington, DC. Available at: https://www.childwelfare.gov/pubPDFs/majorfedlegis.pdf.

73. Children Now (2018) '2018 California children's report card', Oakland. Available at: https://www.childrennow.org/reports-research/2018cachildrensreportcard/.

74. Children Now (no date) 'On a mission to give kids power'. Available at: https://www.childrennow.org/about-us/.

75. Chung $\mathrm{H}$ and Muntaner $\mathrm{C}$ (2008) 'Political and welfare state determinants of infant and children's health indicators: An analysis of wealthy countries', Political and welfare state determinants of infant and child health indicators: An analysis of wealthy countries 7(14)14-31.

76. Clara F, Garcia KY and Metz A (2017) 'Implementing evidence-based child welfare: The New York city experience', SAFE: Seattle. Available at: https://caseyfamilypro-wpengine.netdnassl.com/media/evidence-based-child-welfare-nyc.pdf.

77. Coles E et al. (2016) 'Getting it right for every child: A national policy framework to promote children's wellbeing in Scotland, United Kingdom', The Milbank Quarterly: 94(2)334-65.

78. Connelly D and Rosinsky K (2018a) 'Federal and state/local child welfare agency spending per child, 2004-2014', Child Trends: Bethesda.

79. Connelly D and Rosinsky K (2018b) 'State variation in child welfare agency use of federal funding sources', Bethseda. Available at: https://www.childtrends.org/wp-content/uploads/2018/06/StateVariation-in-Child-Welfare-Agency-use-of-federal-funding-sources_ChildTrends_June2018.pdf.

80. Corwin T, Pecora PJ and Ostrum P (2016) 'Community-based family support: Exemplars with implementation and evaluation strategies', Seattle. Available at: https://caseyfamilyprowpengine.netdna-ssl.com/media/community-based-family-support.pdf.

81. Coulton CJ and Fischer RL (2010) 'Using early child wellbeing indicators to influence local policy and services' in Kamerman SB, Phipps S and Ben-Arieh A (eds) From child welfare to child wellbeing.

Springer: Dordrecht, Heidelberg, London and New York, 101-16. Available at: https://www.springer.com/gb/book/9789048133765.

82. Coulton CJ, Korbin J E and McDonell J (2009) 'Editorial: Indicators of child wellbeing in the context of small areas', Child Indicators Research 2(2)109-10.

83. Council of Australian Governments (2014) 'Protecting children is everyones business' Commonwealth of Australia, Australia.

84. County of Santa Clara Board of Supervisors (2011) 'Child impact statements' County of Santa Clara, California.

85. Cox D and Jones RP (2017) 'Attitudes on child and family wellbeing: National and southeast/southwest perspectives', Washington, DC. Available at: https://www.prri.org/wpcontent/uploads/2017/09/PRRI-Family-Wellbeing.pdf. 
86. Crawford G (1997) 'Foreign aid and political conditionality: Issues of effectiveness and consistency', Democatization, 4(3) 69-108

87. CSSP (2009) 'Setting and measuring benchmarks for state policies: Promoting child safety, permanence, and wellbeing through safe and strong families, supportive communities, and effective systems', CSSP, Washington, DC. Available at: https://www.cssp.org/publications/public-policy/topfive/2_policy-matters-setting-and-measuring-benchmarks-for-state-policies.pdf.

88. Curran MA, Houshyar S and Lesley B (2012) 'Policy connections and practical implications' in Land KC (ed.) The wellbeing of America's children: Developing and improving the child and youth wellbeing index. Springer: Dordrecht, Heidelberg, London and New York, 239-60. Available at: https://link.springer.com/content/pdf/10.1007\%2F978-94-007-4092-1.pdf.

89. Currie JM (2018) 'The kids are all right', Pathways, Standford Centre on Poverty and Inequality: Stanford. Available at: https://inequality.stanford.edu/sites/default/files/Pathways_Winter2018_Kids.pdf.

90. Currie J and Reichman N (2015) 'Policies to promote child health: Introducing the issue', The future of children 25(1)3-9

91. Cusworth $L$ and Bradshaw $J$ (2007) 'A comparison of policies designed to enhance child wellbeing'. Available at: https://www.york.ac.uk/inst/spru/research/pdf/Unicef.pdf.

92. Daly M et al. (2007) Parenting in contemporary Europe: A positive approach. Council of Europe: Strasbourg. Available at: https://book.coe.int/eur/en/children-s-rights-and-family-law/3754-parentingin-contemporary-europe-a-positive-approach.html.

93. Daly M et al. (2015) 'Family and parenting support policy and provision in a global context', UNICEF Office of Research: Innocenti , Florence. Available at: https://www.unicef-irc.org/publications/pdf/01.

94. Dang A-T (2014) 'Amarty Sen's capability approach: A framework for wellbeing evaluation and policy analysis', Review of social economy 72(4)460-84.

95. Danziger S and Waldfogel J (2000) Investing in children: What do we know? What should we do? Centre for Analysis of Social Exclusion, London School of Economics: London. Available at: http://sticerd.Ise.ac.uk/dps/case/cp/CASEpaper34.pdf.

96. Davidson H (2014) 'Does the UN Convention on the rights of the child make a difference?' Michigan State International Law Review 22(2). Available at: https://digitalcommons.law.msu.edu/cgi/viewcontent.cgi?article=1138\&context=ilr.

97. Dejene N et al. (2016) 'The African report on child wellbeing 2016'. African Child Forum, Addis Ababa.

98. Department of Children and Youth Affairs (2016) State of the nations children's report: Ireland 2016. Government Publications: Dublin.

99. Department of Economic and Social Affairs Population Division (2009) Child adoption: Trends and policies. United Nations: New York.

100.Dinisman T and Ben-Arieh A (2016) 'The characteristics of children's subjective wellbeing', Social indicators research 126(2) 555-69.

101. Dryfoos JG and Nissani H (2006) 'Interventions in schools in the US' in McAuley C, Pecora PJ and Rose W (eds) Enhancing the wellbeing of children and families through effective interventions. Jessica Kingsley: London and Philadelphia.

102. Edin KJ and Shaefer LH (2016) \$2.00 a day: Living on almost nothing in America (Kindle Ed.) First Mariner Books: Boston and New York. Available at: https://www.amazon.co.uk/dp/B00QPHNUFO/ref=dp-kindle-redirect?_encoding=UTF8\&btkr=1\%0D.

103. Edwards $F$ (2016a) 'Saving children, controlling families: Punishment, redistribution, and child protection', American sociological review 81(3)575-95. Available at: http://journals.sagepub.com/doi/pdf/10.1177/0003122416638652.

104. Edwards $F(2016 \mathrm{~b})$ 'States which have harsher incarceration and less generous welfare policies tend to place more children in foster care', LSE US centre daily blog on American politics and policy. Available at: http://blogs.Ise.ac.uk/usappblog/2016/10/05/states-which-have-harsher-incarcerationand-less-generous-welfare-policies-tend-to-place-more-children-in-foster-care/ acessed: 3 August 2018).

105. Federal Interagency Forum on Child and Family Statistics (2017) 'America's children: Key national indicators of wellbeing, 2017', Washington, DC.

106. Finck K et al. (2016) 'Child welfare and poverty: The American paradox' in Social justice and policy issues for 2016 presidential election. Philadelphia. Available at: http://www.penntopten.com/wp- 
content/uploads/2016/09/Top-10-Child-Welfare-Poverty-Essay-1.pdf.

107. First Focus (2018) Family First Prevention Services Act Bill summary. Washington, DC. Available at: https://campaignforchildren.org/wp-content/uploads/sites/2/2016/06/FFCC-Short-SummaryFFPSA.pdf.

108. Fitzpatrick J and Kostina-Ritchey E (2014) 'Romantic/marital, parental, and familial relationship policies in the US' in Robila M (ed.) Handbook of family policies across the globe. New York, NY: Springer: New York, 373-87. Available at: https://link.springer.com/chapter/10.1007/978-1-46146771-7 24.

109. Floyd I, Pavetti L and Schott L (2017) 'TANF reaching few poor families'. Washington, DC. Available at: https://www.cbpp.org/sites/default/files/atoms/files/6-16-15tanf.pdf.

110. Folbre N (2008) Valuing children: Rethinking the economics of family. Havard University Press: Boston.

111. Franzoni JM and Voorend K (2011) 'Actors and ideas behind CCTs in Chile, Costa Rica and EI Salvador', Global social policy. Available at: http://journals.sagepub.com/doi/pdf/10.1177/1468018111421296.

112. Frenz P (2007) 'Innovative practice for intersectoral action on health: A case study of four programs for social equity - Chile Barrio, Chile Solidario, Chile Emprende, Chile Contigo', Division of Health Planning Ministry of Health Chile: Santiago. Available at: http://www.who.int/social_determinants/resources/isa_4progs_social_equity_chile.pdf.

113. Fuemmeler BF et al. (2017) 'Child and family health in the era of prevention: New opportunities and challenges', Journal of Behavioral Medicine 40(1):159-74.

114. Gabel SG (2010) 'The development of international comparative child and family policies' in Kamerman SB, Phipps S and Ben-Arieh A (eds) From child welfare to child wellbeing. Springer: Dordrecht, Heidelberg, London and New York, 179-88. Available at: https://www.springer.com/gb/book/9789048133765.

115. Gadsden VL, Ford M and Breiner H (2016) (eds) Parenting matters, National Academies Press: Washington, DC:

116. Gambaro L, Stewart K and Waldfogel J (2015a) 'Equal access to early childhood education and care? The case of the UK' in Gambaro L, Stewart K and Waldfogel J (eds) An equal start: Providing quality early education and care for disadvantaged children. Policy Press: Bristol.

117. Gambaro L, Stewart K and Waldfogel J (2015b) 'Introduction' in Gambaro L, Stewart K and Waldfogel J (eds) An equal start: Providing quality early education and care for disadvantaged children. Policy Press: Bristol.

118. Garfinkela I and Zilanawalab A (2015) 'Fragile families in the American welfare state', Child youth service review 55:210-21.

119. Gilbert N, Parton N and Skivenes M (2011) 'Introduction' in Gilbert N, Parton N and Skivenes M (eds) Child protection systems: International trends and orientations. Oxford University Press: New York. Available at: https://global.oup.com/academic/product/child-protection-systems9780199793358?cc=gb\&lang=en\&\#.

120. Government Accountability Office (2017) Child wellbeing: Key consideration for policy makers. GAO - 18 - 41SP. Washington, DC.

121. Hamm K, Schochet $L$ and Novoa $C$ (2018) 'The Trump plan to cut benefit programs threatens children', Center for American Progress. Available at: https://cdn.americanprogress.org/content/uploads/2018/04/09130615/HammYoungChildrenWillBeHa rmedByBenefitsCuts-report.pdf.

122. Hartnett MA et al. (2009) 'Illinois child wellbeing study: Year two final report', Urbana. Available at: https://cfrc.illinois.edu/pubs/rp_20090101_IllinoisChildWellbeingStudyYearTwoFinalReport.pdf.

123. Hatton S (no date) Improving health and wellbeing for children and families: update on the national health visiting programme - an integrated approach. Health Education England: London.

124. Herbst CM and Tekin E (2010) 'Child care subsidies and child development', Economics of Education review 29:618-38.

125. Hernandez DJ and Cervantes WD (2011) Children in immigrant families: Ensuring opportunity for every child in America. First Focus and Foundation for Child Development, New York. Available at: https://firstfocus.org/wp-content/uploads/2014/06/Children-in-Immigrant-Families-EnsuringOpportunity-for-Every-Child-in-America.pdf.

126. Heward C and Bunware S (1999) Gender, education and development. Zed Books: London. 
127. Hoagwood KE et al. (2014) 'Scaling up evidence-based practices for children and families in New York State: Toward evidence-based policies on implementation for state mental health systems', Journal of clinical child \& adolescent psychology 43(2):145-57

128. Howard J (2018a) 'Among 20 wealthy nations, US child mortality ranks worst, study finds'. CNN. Available at: https://edition.cnn.com/2018/01/08/health/child-mortality-rates-by-country-studyintl/index.html.

129. Howard J (2018b) 'The cost of child care around the world', CNN.

130. Hoynes HW and Schanzenbach DW (2018) Saftey net investments in children. National Bureau of Economic Research: Cambridge.

131. Hudson $\mathrm{J}$ and Kuhner S (2016) Fairness for children: A league table of inequality in child wellbeing in rich countries. UNICEF: Florence. Available at: https://www.unicefirc.org/publications/pdf/RC13_eng.pdf.

132. Huntington $C$ and Scott $E(2015)$ 'Children's health in a legal framework', The future of children 2(1):177-97.

133. Illinois Department of Children and Family Services (2016) 'Illinois child welfare transformation: 2016-2021 strategic plan'. Chicago.

134. Institute of Public Care (2010) Early intervention and prevention with children and families: Getting the most from team around the family systems. Oxford Brooks University: Oxford.

135. James Bell Associates (2016) Summary of the Title IV-E. James Bell Associates: Arlington.

136. Jarrett $\vee(2015)$ 'Champions of change: Advocating for working families', White House blog, available at https://obamawhitehouse.archives.gov/blog/2015/04/17/champions-change-advocating-workingfamilies.

137. Jenson J (2004) 'Changing the paradigm: Family responsibility or investing in children', Canadian journal of sociology 29(2):169-92

138. Jordan E and Connelly DD (2016) 'An introduction to child welfare funding, and how states use it'. Bethseda. Available at: https://www.childtrends.org/wp-content/uploads/2016/01/201601 IntroStateChildWelfareFunding.pdf.

139. Kamerman SB (2010) 'Child, family, and state: The relationship between family policy and social protection policy' in Kamerman SB, Phipps S and Ben-Arieh A (eds) From child welfare to child wellbeing. Springer: Dordrecht, Heidelberg, London and New York:429-37. Available at: https://www.springer.com/gb/book/9789048133765.

140. Kamerman SB and Kahn AJ (2001) 'Child and family policies in the United States at the opening of the twenty-first century', Social policy and administration 35(1):69-84.

141. Kamerman SB and Kahn AJ (2002) 'Child and family policies in the United States at the opening of the twenty-first century', Social policy administration. Available at: 35(1): 69-84

142. Kamerman SB, Phipps S and Ben-Arieh A (2010) 'From child welfare to child wellbeing an international perspective on knowledge in the service of policy making' in Kamerman SB, Phipps $S$ and Ben-Arieh A. (eds) From child welfare to child wellbeing. Springer: Dordrecht, Heidelberg, London and New York.

143. Kemp SP et al. (no date) 'Family support services' in Mallon GP and Hess PM (eds) Child welfare for the twenty-first century: A handbook of practices, policies, and programs (2nd ed). Columbia University Press: New York. Available at: https://cup.columbia.edu/book/child-welfare-for-the-twentyfirst-century/9780231151801.

144.Klein A (2015) 'No child left behind: An overview', Education week. Available at: https://www.edweek.org/ew/section/multimedia/no-child-left-behind-overview-definitionsummary.html.

145. Klein A (2016) 'The Every Student Succeeds Act: An ESSA overview', Education week. Available at: https://www.edweek.org/ew/issues/every-student-succeeds-act/index.html.

146. Klein A (2018) 'Q\&A: Making the most of "Continuous improvement" in the US', Education week.

147. Kuebler D (2007) 'Understanding the recent expansion of Swiss family policy: An idea-centred approach', Journal of social policy 36(2):217-2-37.

148. Lamb ME (2009) 'Child care and new family forms' inChanging childhood in a changing Europe: Interdisciplinary workshop report. European Science Foundation: Strasbourg,11-16. Available at: http://archives.esf.org/fileadmin/Public_documents/Publications/Changing_Childhood.pdf.

149. Land KC (2014a) 'Child and youth Wellbeing Index (CWI) report'. Durham. Available at: https://childandfamilypolicy.duke.edu/wp-content/uploads/2014/12/Child-Wellbeing-Report.pdf. 
150. Land KC (2014b) 'Child wellbeing index', Centre for child and family policy: Duke University. Available at: http://www.soc.duke.edu/\%7B \%7Dcwi/Section_H/index.html.

151. Land KC, Lamb V and Zheng H (2009) 'How are the kids doing? How do we know', Social indicators research 100, 463-77.

152. Lansdown G (2011) Every child's right to be heard. Save the Children and UNICEF: London.

153. Lichter DT (2018) 'The unsuccessful family experiment', Pathway (Winter).

154. Linden $M$ et al. (2008) 'The children's budget 2008'. Washington, DC. Available at: https://firstfocus.org/wp-content/uploads/2010/03/Childrens-Budget-2008.pdf.

155. Lippman L (2005) 'Indicators and indices of child wellbeing: A brief American history. Social indicators research, 83(1): 39 - 53

156. Lister R (2003) 'Investing in the citizen-workers of the future: Transformations in citizenship and state under new labour', Social policy and administration 37(5). Available at: https://onlinelibrary. wiley.com/doi/abs/10.1111/1467-9515.00350.

157. Lister R (2006) 'Children (but not women) first: New Labour, child welfare and gender', Critical social policy. Available at: http://journals.sagepub.com/doi/pdf/10.1177/0261018306062588.

158. Lister R (2008) 'Investing in children and childhood: A new welfare policy paradigm and its implications' in Leira A and Saraceno C (eds) Childhood: Changing contexts. Emerald Group Publishing Limited, 383-408. Available at: https://www.emeraldinsight.com/doi/pdfplus/10.1016/S0195-6310\%2807\%2900013-0.

159. Loewenson R (1993) 'Structural adjustment and health policy in Africa', International journal of health services. 23(4): 717-730.

160. Loewenson R and Masotya M (2018) 'An analytic framework for gathering evidence on the drivers of policy prioritisation of child and family health and wellbeing'. Training and Research Support Centre

161. Lundy L et al. (2012) The UN Convention on the Rights of the Child: A study of the legal implementation in 12 countries. Belfast. Available at: https://www.qub.ac.uk/researchcentres/CentreforChildrensRights/filestore/Filetoupload,368351,en.pdf.

162. Mag AG (2015) 'Promoting children's wellbeing: Policies, practices and current trends', Procediasocial and behavioral sciences, 180:1391-97.

163. Magnuson $\mathrm{K}$ and Waldfogel $\mathrm{J}$ (2014) 'Delivering high-quality early childhood education and care to low-income children: How well is the US doing?' in Gambaro L, Stewart K and Waldfogel J (eds) An equal start?: Providing quality early education and care for disadvantaged children (1st ed) Policy Press, Bristol University Press: Bristol,193-218. Available at: https://www.jstor.org/stable/j.ctt9qgznh.

164. Mallon GP and Hess PM (2014) 'Part 1: Child and adolescent wellbeing' in Mallon GP and Hess PM (eds) Child welfare for the twenty-first century: A handbook of practices, policies, and programs. Columbia University Press: New York. Available at: https://cup.columbia.edu/book/child-welfare-forthe-twenty-first-century/9780231151801.

165. Mallon GP and Hess PM (2014) 'Introduction' in Mallon GP and Hess PM (eds) Child welfare for the 21st century: A handbook of practices, policies and programmes ( 2 nd ed).Columbia University Press: New York.

166. McAuley C, Morgan R and Rose W (2010) 'Children's views on child wellbeing' in McAuley C and Rose W (eds) Child wellbeing: Understanding children's lives. Jessica Kingsley: London and Philadelphia. Available at: https://www.jkp.com/uk/child-wellbeing-2.html/.

167. McAuley C and Rose W (2010a) 'Child wellbeing: Current issues and future directions' in McAuley C and Rose W (eds) Child wellbeing: Understanding children's lives. Jessica Kingsley: London and Philadelphia, 207-18. Available at: https://www.jkp.com/uk/child-wellbeing-2.html/.

168. McAuley C and Rose W (2010b) 'Child wellbeing: Looking towards the future' in McAuley C and Rose W (eds) Child wellbeing: Understanding children's lives. Jessica Kingsley: London and Philadelphia. Available at: https://www.jkp.com/uk/child-wellbeing-2.html/.

169. McCarty AT (2016) 'Child poverty in the United States: A tale of devastation and a promise of hope', Social compass 10(7):623-29.

170. McCroskey J (2006) 'Community programmes in the US' in McCauley C, Percora PJ and Rose W. (eds) Enhancing the wellbeing of children and families through effective interventions: International evidence for practice. Jessica Kingsley: London and Philadelphia. Available at: https://www.jkp.com/uk/enhancing-the-wellbeing-of-children-and-families-through-effectiveinterventions-2.html.

171. McGowan B (2014) 'Historical evolution of child welfare services' in Mallon GP and Hess PM (eds) 
Child welfare for the twenty-first century: A handbook of practices, policies, and programs. Columbia University Press: New York. Available at: https://cup.columbia.edu/book/child-welfare-for-the-twentyfirst-century/9780231151801.

172. Mehta M (2015) 'There's only one country that hasn't ratified the Convention on Children's Rights: US', ACLU blog. Availabile at: https://www.aclu.org/blog/human-rights/treaty-ratification/theres-onlyone-country-hasnt-ratified-convention-childrens

173. Mekonen Y (2009) The Child-Friendless Index: A new tool to assess government performance. The African Child Policy Forum: Addis Ababa.

174. Merker R (2017) 'Children's budget 2017'. Washington, DC. Available at: https://www.dropbox.com/s/wwec7f3fhzxr2bw/Childrens-Budget-2017.pdf?dl=0.

175. Meyers MK, Gornick JC and Peck LR (2001) 'Packaging support for low-income families: Policy variation across the United States', Journal of policy analysis and management, 20(3). Available at: https://onlinelibrary.wiley.com/doi/abs/10.1002/pam.1003.

176. Miller O and Esenstad A (2015) Strategies to reduce racially disparate outcomes in child welfare. CSSP: New York. Available at: https://www.cssp.org/publications/child-welfare/alliance/Strategies-toReduce-Racially-Disparate-Outcomes-in-Child-Welfare-March-2015.pdf.

177. Mistry KB et al. (2012) 'A new framework for childhood health promotion: The role of policies and programs in building capacity and foundations of early childhood health', American journal of public health 102(9):1688-96.

178. Mitchell T (2018) 'Some House leaders ignore evidence, cite flawed reports to justify taking basic assistance away from needy indivduals'. Washington, DC. Available at: https://www.cbpp.org/sites/defaultfiles/atoms/files/4-18-18tanf.pdf.

179. Mitchell T, Pavetti L and Huang Y (2018) 'Life after TANF in Kansas: For most, unsteady work and earnings below half the poverty line'. Washington, DC. Available at: https://www.cbpp.org/sites/default/files/atoms/files/1-23-18kstanf.pdf.

180. Moloney, L, Weston, R and Hayes, A (2013) 'Key social issues in the development of Australian family law: Research and its impact on policy and practice', Journal of Family Studies 19(2): 110138.

181. Mulinge MM (2002) 'Implementing the 1989 United Nations' Convention on the Rights of the Child in sub-Saharan Africa: The overlooked socioeconomic and political dilemmas', Child abuse and neglect 26(11):1117-30.

182. Nanji N, Nanji N and Manji F (1991) 'From development to sustained crisis: Structural adjustment, equity and health', Social science and medicine 33(9):985-93.

183. National Institute on Drug Abuse (2007) Community monitoring systems: Tracking and improving the wellbeing of America's children and adolescents. U.S. Department of Health and Human Services National Institutes of Health: Washingon, DC.

184. Nayowith GB (2010) 'Fact-based child advocacy: The convergence of analysis, practice, and politics in New York' in Kamerman SB, Phipps S and Ben-Arieh A (eds) From child welfare to child wellbeing. Springer: Dordrecht, Heidelberg, London and New York. Available at: https://www.springer.com/gb/book/9789048133765.

185. New Economics Foundation (2004) A wellbeing manifesto for a flourishing society. New Economics Foundation: London.

186. New Mexico Voices for Children (2013) Kids are counting on us: A policy agenda for a better New Mexico. New Mexico Voices for Children: Albuquerque.

187. New Mexico Voices for Children (2018) New Mexico kids at the crossroads 2018: A children's agenda for making KIDS COUNT with candidates. New Mexico Voices for Children: Albuquerque.

188. New York State (2018) 'New York State paid family leave: Employee facts, paid family leave. New York State: New York

189. Nolen AB (2014) 'Desk review of primary care in the United States of America', USA for Training and Research Support Centre, University of Texas Medical Branch: Galveston.

190. O'Hare WP et al. (2013) 'Analyzing differences in child wellbeing among US states', Child indicators research 6(401-431):197.

191. OECD (2017a) 'Family benefits public spending'. OECD: Paris.

192. OECD (2017b) 'OECD Family Database'. OECD: Paris.

193. OECD (2017c) 'Parental leave system'. OECD: Paris.

194. OECD (2017d) 'Starting strong 2017: Key OECD indicators on early childhood education and care'. 
OECD: Paris. Available at: http://www.charlotte-buehler-institut.at/wpcontent/uploads/2017/10/Starting-Strong-2017.pdf.

195. OECD (no date) 'Universal health coverage', Health policies and data. Available at: http://www.oecd.org/els/health-systems/universal-health-coverage.htm

196. OII (2018) 'Promise neighbourhoods (PN)'. Available at: https://innovation.ed.gov/what-wedo/parental-options/promise-neighborhoods-pn/

197. Orange County Social Services Agency (no date) 'Families and communities together, Fact', Orange County, California

198. Organisation for Economic Co-operation and Development (2017) 'How does the United States compare on child wellbeing'. Paris: OECD.

199. Palley E and Shdaimah CS (2014) In our hands: The struggle for U.S. child care policy. New York University Press: New York. Available at: https://www.jstor.org/stable/j.ctt9qgdcg.

200. Parton N and Skivenes M (2011) 'Child protection in England' in Gilbert N, Parton N and Skivenes M (eds) Child protection systems: International trends and orientations. Oxford University Press: Oxford.

201.Pecora PJ and Harrison-Jackson M (2010) 'The challenege of improving children's wellbeing and measuring outcomes: An American perspective' in McAuley C and Rose W (eds) Child wellbeing: Understanding children's lives. Jessica Kingsley: London and Philadelphia, 161-80.

202.Pecora PJ, McAuley C and Rose W (2006) 'Effectiveness of child welfare interventions' in McAuley $\mathrm{C}$, Pecora PJ and Rose W (eds) Enhancing the wellbeing of children and families through effective interventions: International evidence for practice. Jessica Kingsley: London and Philadephia. Available at: https://www.jkp.com/uk/enhancing-the-wellbeing-of-children-and-families-througheffective-interventions-2.html.

203. Piachaud D and Sutherland H (2001) 'Child poverty in Britain and the New Labour government', Journal of social policy 30(1):95-118.

204.Pickett K and Wilkinson RG (2015) 'The ethical and policy implications of research on income inequality and child wellbeing', Pediatrics 135(S32):S39--S47.

205.PNI (2018) 'Pathways to success, from cradle to career'. Available at: http://www.promiseneighborhoodsinstitute.org/

206. Policy for Results (2012) Promoting children's social, emotional and behavioural health. Centre for the Study of Social Policy: Washington, DC.

207.Popay J et al. (2006) 'Guidance on the conduct of narrative synthesis in systematic reviews: A product from the ESRC Methods Programme'. Institute for Health Research, University of Lancaster: Lancaster.

208.Prilleltensky I and Nelson G (2000) 'Promoting child and family wellness: Priorities for psychological and social interventions', Journal of community and applied social psychology 10:85-105.

209. Radel L (2005) 'How and why the current funding structure fails to meet the needs of child welfare field'. Washington, DC. Available at: https://aspe.hhs.gov/system/files/pdf/177496/ib.pdf.

210. Richardson D (2014) 'International comparisons of child wellbeing' in Ben-Arieh A et al. (eds) Handbook of Child Wellbeing: Theories, Methods and Policies in Global Perspective. Dordrecht, Heidelberg, London, New York: Springer,3219-48.

211. Robbins KG and Fremstad S (2016) '4 progressive policies that make families stronger'. Washington, DC. Available at: https://www.americanprogress.org/issues/poverty/reports/2016/10/25/225731/4progressive-policies-that-make-families-stronger/.

212. Rosanbalm KD et al. (2016) 'Child wellbeing assessment in child welfare: A review of four measures', Children and youth services review 68:1-16.

213. Rose W and Rowlands J (2010) 'Introducing the concept of child wellbeing into government policy' in McAuley C and Rose W (eds) Child wellbeing: Understanding children's lives. Jessica Kingsley: London and Philadelphia, 67-90. Available at: https://www.jkp.com/uk/child-wellbeing-2.html/.

214. Rossen LM (2014) 'Neighbourhood economic deprivation explains racial/ethnic disparities in overweight and obesity among children and adolescents in the USA', Journal of epidemiology and community health 68(2):123-29. Available at: https://www.ncbi.nlm.nih.gov/pubmed/24072744.

215. Rothschild A (2007) 'Is America holding out on protecting children's rights', The Atlantic. Available at: https://www.theatlantic.com/education/archive/2017/05/holding-out-on-childrens-rights/524652/.

216. RWJF and Changemakers (no date) 'Children's wellbeing, Available at https://www.changemakers.com/childrenswellbeing. 
217. Saavedra M (2017) 'Children's health insurance, family income, and welfare enrollment', Child youth services review 73:182-86.

218. Sandin B (2014) 'History of child wellbeing' in Ben-Arieh A et al. (eds) Handbook of child wellbeing: Theories, methods and policies in global perspective. Springer: Dordrecht, Heidelberg, London and New York, 31-86. Available at: https://link.springer.com/referencework/10.1007\%2F978-90-4819063-8?page=1\#toc.

219. Save the Children (2016) Economic playgrounds: Comparing the lives of children in G20 countries. London.

220. Save the Children (2018a) 'Growing up rural in America'. Connecticut. Available at: https://www.savethechildren.org/content/dam/global/reports/2018-end-of-childhood-report-us.pdf.

221. Save the Children (2018b) 'The many faces of exclusion: End of childhood report 2018'. London.

222. Schaefer S, Gates S and Kiernan M (2010) 'Strengthening New York business through investments in early care and education'. America's edge, New York.

223. Schaefer S, Gates S and Warner L (2012) 'Boosting New York's economy: Short and long-term economic gains through quality early learning'. New York. Available at: http://www.rauchfoundation.org/files/4213/5214/6583/NY-AE-Early-Ed-Quality-Report.pdf.

224. Schalick ML (2014) 'Bio family 2.0: Can American child welfare system finally find permanency for legal orphans with a statute to reinstate parental rights?' University of Michigan journal of law reform 47(2). Available at: https://repository.law.umich.edu/cgi/viewcontent.cgi?article=1034\&context=mjlr.

225. Schellenbach C, Culp AM and Nguyen L (2013) 'The wellbeing of children in the United States: Evidence for a call for action' in Culp AM (ed.) Child and family advocacy: Bridging the gaps between research, practice and policy. Springer: New York, Heidelberg, Dordrecht and London.

226. Schott L, Floyd I and Burnside A (2018) 'How states use funds under the TANF bloc grant'. Washington, DC. Available at: https://www.cbpp.org/sites/default/files/atoms/files/1-5-17tanf.pdf.

227. Schott $L$ and Pavetti $L$ (2018) 'Potential changes to House TANF bill's "Universal Engagement" approach would discourage states from helping those with greatest needs'. Centre on Budget and Policy Priorities: Washington, DC.

228. Schulte B (2014) 'The U.S. ranks last in every measure when it comes to family policy in 10 charts', Washington Post. Available at: https://www.washingtonpost.com/blogs/she-thepeople/wp/2014/06/23/global-view-how-u-s-policies-to-help-working-families-rank-in-theworld/?noredirect=on\&utm_term $=.398878873021$.

229. Seccombe K (2002) "Beating the odds" Versus 1 Changing the Odds": Poverty, resilience and family policy', Journal of marriage and family 64:384-94.

230. Seligman M and Adler A (2018) ‘Positive education' in Global happiness: Policy report 2018. Sustainable Development Solutions Network: New York. Available at: https://www.worldgovernmentsummit.org/api/publications/document?id=304a8bc4-e97c-6578-b2f8ff0000a7ddb6.

231. Settersten RA, Mcclelland MM and Miao A (2014) 'Child wellbeing and the lifecourse' in Ben-Arieh A et al. (eds) Handbook of child wellbeing: Theories, methods and policies in global perspective. Springer: Dordrecht, Heidelberg, New York and London, 679-711.

232. Seymoor D (2009) 1989 - 2009: Convention brings progress on child rights but challenges remain. CRC blog 20 years of the CRC. Avalable at: https://www.unicef.org/rightsite/237_241.htm.

233. Shaefer LH and Edin K (2018) 'Welfare reform and the families it left behind'. Available at: https://inequality.stanford.edu/sites/default/files/Pathways_Winter2018_Families-Left-Behind.pdf.

234. Shelby County (no date) 'Office of early childhood and youth'. Available at: http://www.shelbycountytn.gov/2438/Office-of-Early-Childhood-and-Youth

235. Sherman A (2009) 'Stimulus keeping 6 million Americans out of poverty in 2009, estimates show'. Washington, DC. Available at: https://www.cbpp.org/research/stimulus-keeping-6-million-americansout-of-poverty-in-2009-estimates-show.

236. Sherman A and Tazar M (2017) 'Economic security programmes help low-income children suceed over the long-term', Challenge 60(6):514-42.

237. Sherman A, Trisi D and Parrott S (2013) 'Various supports for low-income families reduce poverty and have long-term positive effects on families and children'. Centre on Budget and Policy Priorities Washington, DC.

238. Shields MK and Behrman RE (2002) 'Child welfare reform: Analysis and recommendations', The future of children 12(1):4-25. 
239. Ssewamala FM (2015) 'Optimizing the "demographic dividend" in young developing countries: The role of contractual savings and insurance for financing education', International journal of social welfare 24(3):248-62.

240.Standford Centre on Gender and Poverty Inequality (2011) '20 facts about U.S. inequality that everyone should know', Pathways.

241.Stanton EA (2007) 'The human development index: A history'. Available at: https://scholarworks.umass.edu/cgi/viewcontent.cgi?article=1101\&context=peri_workingpapers.

242. Starke P, Obinger $\mathrm{H}$ and Castles FG (2008) 'Convergence towards where: In what ways, if any, are welfare states becoming more similar?' Journal of European public policy 15(7):975-1000.

243. Stoltzfus E (2017) 'Child welfare: An overview of federal programs and their current funding'. Available at: https://fas.org/sgp/crs/misc/R43458.pdf.The Children's Defence Fund (2017) The State of America's children 2017. Washington, DC.

244. The Children's Defence Fund (2018) 'The Family First Prevention Services Act'. Washington, DC: Http://www.childrensdefense.org/library/data/ffpsa-short-summary.pdf.

245. The Children's Defence Fund Cailfornia (2018) 'Leveling the playing field for California's children: 2018 policy agenda'. The Children's Defence Fund California: Los Angeles.

246. The Children's Partnership and The Children's Defence Fund California (2018) 'Building California's future: 2018 election guide. The Children's Partnership and The Children's Defence Fund California Los Angeles.

247. The Children's Society (2012) The good childhood report: Promoting positive wellbeing for children. The Children's Society: London.

248. The National Academies of Sciences, Enginnering and Medicine (NASEM) (2016) Parenting matters: Supporting children ages 0-8. The National Academies Press: Washington, DC.

249. The National Institute for Early Education Research (2018) 'The state of preschool 2017'. Rutgers Graduate School of Education, Rutgers University: New Brunswick.

250. Tisdall EKM (2015) 'Children's rights and children's wellbeing: Equivalent policy concepts?' International social policy 44(4):807-23.

251.Torres A et al. (2017) 'Chile Crece Contigo: Implementation, results, and scaling-up lessons', Child, healthcare and development 44(1):4-11.

252. Training and Research Support Centre (2014) 'Strengthening primary care in the USA to improve health: Learning from high- and middle-income countries'. Training and Research Support Centre:

253. Trostel P (2013) Path to a better future: The fiscal payoff of investment in early childhood development in Maine. Margaret Chase Smith Policy Centre and School of Economics, University of Maine: Bangor.

254. Tsai M-C and Chen W (2017) (eds) The family-work nexus and wellbeing in Asia: An introduction. Springer: Singapore. Available at: https://link.springer.com/chapter/10.1007/978-981-10-4313-0_1.

255. Tucker $L$ (2018a) 'California maternity leave: Everything expectant parents need to know (Including big changes in 2018)', Working mother. Available at: https://www.workingmother.com/californiamaternity-leave-everything-expectant-parents-need-to-know.

256. Tucker $L$ (2018b) 'New Jersey maternity leave 101: Everything expectant parents need to know', Working mother. Available at: https://www.workingmother.com/new-jersey-maternity-leave-101everything-expectant-parents-need-to-know.

257.Udall T (2015) 'Saving Our Next Generation (SONG) Act'. SCRIBD. Available at: https://www.scribd.com/document/255577820/Saving-Our-Next-Generation-SONG-Act\#download.

258.UNICEF (2007) 'Protecting the world's children: Impact of the Convention on the Rights of the Child', UNICEF: New York, NY. Available at: http://www.cambridge.org/gb/academic/subjects/law/humanrights/protecting-worlds-children-impact-convention-rights-child-diverse-legalsystems?format=HB\&isbn=9780521875134.

259. UNICEF (2015a) 'Children and reseach at Innocenti: 25 years of UNICEF Commitment',Florence: United Nations: Florence.

260.UNICEF (2015b) State of the Worlds Children: A fair start for every child. UN: New York.

261. UNICEF (no date a) 'Aspiring happiness for every child in Bhutan'. Available at: https://www.unicef.org/infobycountry/files/BHUTAN_Investment_Case_Aspiring_happiness_for_ever y_child_in_Bhutan_2016_08_22.pdf.

262. UNICEF (no date b 'History of Innocenti'. Available at: https://www.unicefirc.org/history_of_innocenti/ 
263. UNICEF (no date c) 'Where we work'. Available at: https://www.unicef.org/where-we-work\#A

264. United Nations (2015) 'The World Economic Forum and social survey 2014/2015: Learning from national policies supporting MDG implementation', New York, NY. Available at:

https://www.un.org/development/desa/dpad/publication/world-economic-and-social-survey20142015-learning-from-national-policies-supporting-mdg-implementation/.

265. Ura A (2017) 'How Texas killed welfare: "We spend our dollars on anything but poor families"', Guardian.

266. Waldfogel J et al. (2001) 'Welfare reform and lone mothers' employment in the US', Centre for Analysis of Social Exclusion, London School of Economics: London. Available at: http://sticerd.Ise.ac.uk/dps/case/cp/CASEpaper47.pdf.

267. Waldfogel J (2006) What children need. Cambridge and London: Harvard University Press: Cambridge and London.

268. Waldfogel J (2007) Welfare reforms and child wellbeing in the US and UK. London. Available at: http://sticerd.Ise.ac.uk/dps/case/cp/CASEpaper126.pdf.

269. Waldfogel J (2009) 'Prevention and the child protection system', Future child 19(2):95-210. Available at: https://www.ncbi.nlm.nih.gov/pubmed/19719028.

270.Waldfogel J (2010) Britain's war on poverty. Russell Sage Foundation: New York.

271. Walker NE, Brooks CM and Wrightsman LS (1999) Children's rights in the United States: In search of a national policy. Sage: Thousand Oaks, London and New Delhi.

272. Wallin A (2018) 'Moving the needle on child wellbeing', Albuquerque. Available at: https://www.nmvoices.org/wp-content/uploads/2018/04/Moving-Needle-rpt-2018-web.pdf.

273. Waterhouse P, Hill AG and Hinde A (no date) 'Combining work and child care: The experiences of mothers in Accra, Ghana', Development of southern Africa 34(6). Available at: https://www.tandfonline.com/doi/pdf/10.1080/0376835X.2017.1323627?needAccess=true.

274. Webster D, Needell B and Wildfire J (2002) 'Data are your friends: Child welfare agency selfevaluation in Los Angeles county with the family to family initiative', Children and youth services review 24(6-7):471-84.

275. Weisner TS (2014) 'Culture, context, and child wellbeing' in Ben-Arieh A et al. (eds) Handbook of child wellbeing: Theories, methods and policies in global perspective. Springer: Dordrecht, Heidelberg, London and New York. Available at: https://link.springer.com/referencework/10.1007\%2F978-90-481-9063-8?page=1\#toc.

276. Wexler R (2018) 'Don't believe the hype: The Family First Act is a step backwards for child welfare', Health impact news. National Coalition for Child Protection Reform.

277. Workman S et al. (no date) 'Top 10 early childhood ideas for states in 2018', Early childhood. Center for American Progress. Available at: https://www.americanprogress.org/issues/earlychildhood/reports/2018/03/14/447867/top-10-early-childhood-ideas-states-2018/

278. World Atlas (no date) 'Countries with universal health care'. Available at: https://www.worldatlas.com/articles/countries-with-universal-health-care.html 


\section{Acronyms}

$\begin{array}{ll}\text { ACA } & \text { Affordable Care Act } \\ \text { ACRWC } & \text { African Charter on the Rights and Welfare of the Child } \\ \text { AFDC } & \text { Aid to Families with Dependent Children } \\ \text { AECF } & \text { Annie E Casey Foundation } \\ \text { AACF } & \text { Arkansas Advocates for Children and Families } \\ \text { CSSP } & \text { Centre for the Study of Social Policy } \\ \text { CHIP } & \text { Children's Health Programme } \\ \text { CRC } & \text { Convention on the Rights of the Child } \\ \text { CSCBS } & \text { County of Santa Clara Board of Supervisors } \\ \text { CTC } & \text { Child Tax Credit } \\ \text { ECEC } & \text { Early Childhood Education and Care } \\ \text { EITC } & \text { Earned Income Tax Credit } \\ \text { FCHW } & \text { Family and Child Health and Wellbeing } \\ \text { FCSI } & \text { Fostering and Connections to Success and Increasing Adoption Act } \\ \text { INGO } & \text { International Non-Governmental Organisation } \\ \text { MDG } & \text { Millennium Development Goal } \\ \text { NASEM } & \text { National Academies of Sciences, Engineering and Medicine } \\ \text { NEF } & \text { New Economics Foundation } \\ \text { NMFC } & \text { New Mexico Voices for Children } \\ \text { NGO } & \text { Non-Governmental Organisation } \\ \text { OCHCA } & \text { Orange County Health Care Agency } \\ \text { OECD } & \text { Organisation for Economic Co-operation and Development } \\ \text { SNAP } & \text { Supplemental Nutrition Assistance Program } \\ \text { SDG } & \text { Sustainable Development Goal } \\ \text { TANF } & \text { Temporary Assistance for Needy Families } \\ \text { GAO } & \text { U.S. Government Accountability Office } \\ \text { UNICEF } & \text { United Nations Children's Fund }\end{array}$




\section{Appendix 1}

Figure A1: A framework for retrospective policy analysis of drivers of policy shifts in FCHW

(3)WHAT CONTEXT FOR THE POLICY SHIFT? RELEVANT STRUCTURAL FACTORS? Demography, political economy, laws, state capacities RELEVANT SITUATIONAL FACTORS? Temporary conditions, Focusing events, crisis, political transitions RELEVANT SOCIO-CULTURAL FACTORS? Values, norms, Beliefs, religion RELEVANT INTERNATIONAL FACTORS? Norms, agreements, meetings, Resources, conditionality OTHER CONTEXT FACTORS?

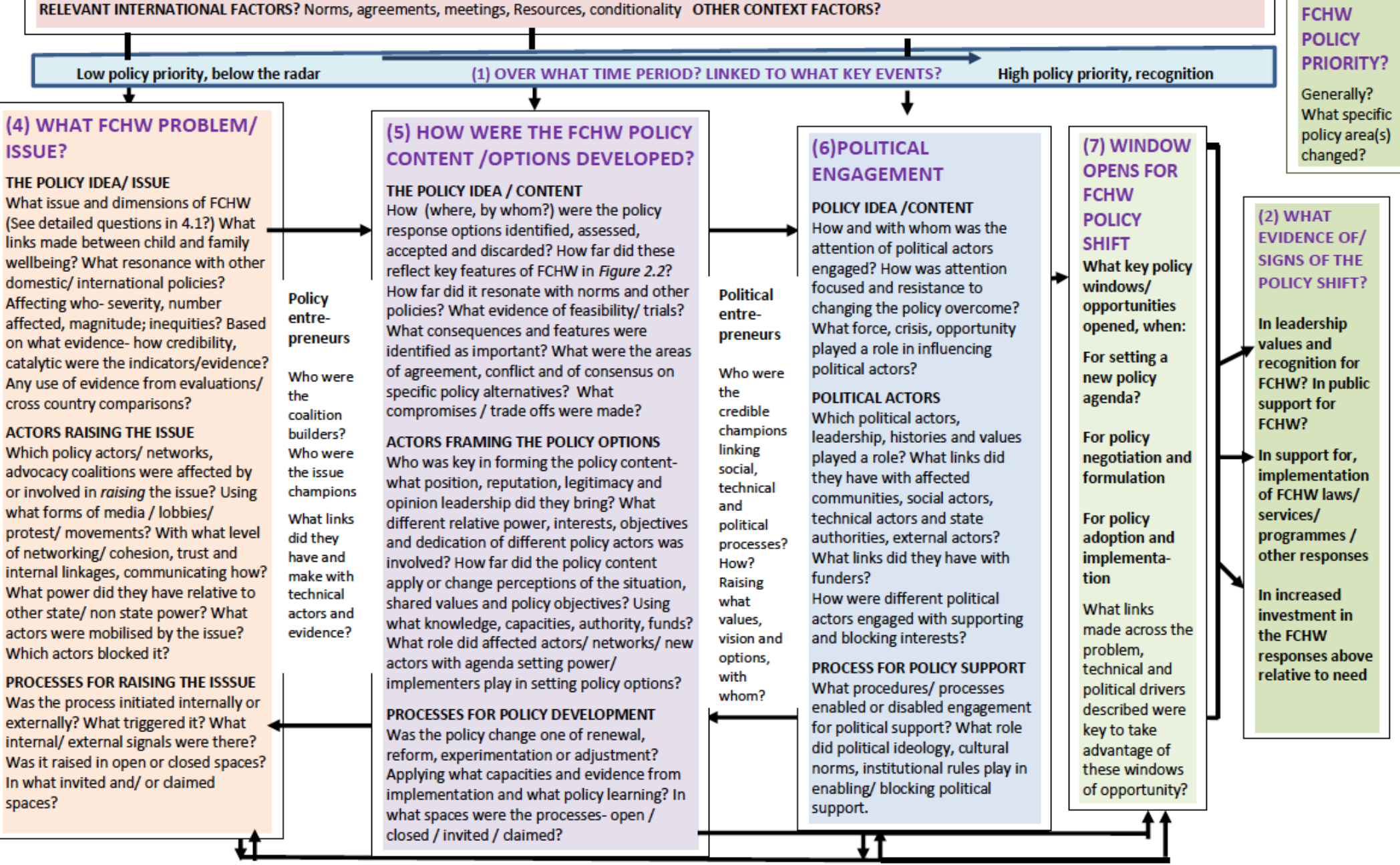

Loewenson and Masotya, 2018 
Table A2: Top 5 Countries and USA rank on indexes of child wellbeing and other indicators

\begin{tabular}{|c|c|c|c|c|c|c|c|c|}
\hline Index/indicator & $\begin{array}{l}\text { UNICEF } \\
\text { Index of } \\
\text { children in } \\
\text { rich } \\
\text { countries } \\
2013\end{array}$ & $\begin{array}{l}\text { Child } \\
\text { prosperity } \\
\text { index G20 } \\
\text { countries, } \\
2016\end{array}$ & $\begin{array}{l}\text { End of } \\
\text { childhood } \\
2018\end{array}$ & $\begin{array}{l}\text { League table } \\
\text { child - } \\
\text { relevant SDG } \\
\text { goals, } 2017\end{array}$ & $\begin{array}{l}\text { League table } \\
\text { of inequality }\end{array}$ & $\begin{array}{l}\text { Subjective } \\
\text { life } \\
\text { satisfaction }\end{array}$ & $\begin{array}{l}\text { OECD family } \\
\text { benefits } \\
\text { public } \\
\text { spending, \% } \\
\text { of GDP } \\
2016\end{array}$ & $\begin{array}{l}\text { OECD public } \\
\text { spending on } \\
\text { ECEC, \% of } \\
\text { GDP } \\
2016\end{array}$ \\
\hline Top 5 countries & $\begin{array}{l}\text { Netherlands } \\
\text { Norway } \\
\text { Iceland } \\
\text { Finland } \\
\text { Sweden }\end{array}$ & $\begin{array}{l}\text { Germany } \\
\text { France } \\
\text { Japan } \\
\text { Australia } \\
\text { Canada }\end{array}$ & $\begin{array}{l}\text { Singapore } \\
\text { Slovenia } \\
\text { Norway } \\
\text { Sweden } \\
\text { Finland }\end{array}$ & $\begin{array}{l}\text { Norway } \\
\text { Germany } \\
\text { Denmark } \\
\text { Sweden } \\
\text { Finland }\end{array}$ & $\begin{array}{l}\text { Denmark } \\
\text { Finland } \\
\text { Norway } \\
\text { Switzerland } \\
\text { Austria }\end{array}$ & $\begin{array}{l}\text { Netherland } \\
\text { Iceland } \\
\text { Spain } \\
\text { Finland } \\
\text { Greece }\end{array}$ & $\begin{array}{l}\text { UK } \\
\text { Denmark } \\
\text { France } \\
\text { Sweden } \\
\text { Iceland }\end{array}$ & $\begin{array}{l}\text { Iceland } \\
\text { Sweden } \\
\text { Denmark } \\
\text { France } \\
\text { Norway }\end{array}$ \\
\hline USA rank & $26 / 29$ & $9 / 19$ & $36 / 175$ & $37 / 41$ & $18 / 35$ & $23 / 29$ & $24 / 26$ & $34 / 37$ \\
\hline
\end{tabular}

Adamson, 2013; Bradshaw et al., 2013; Hudson and Kuhner, 2016; OECD, 2016, 2017d, Save the Children, 2016, 2018b; Brazier, 2017

Table A3: Measuring child wellbeing in the USA top and bottom 5 states

\begin{tabular}{|c|c|c|c|c|c|c|c|}
\hline Indicator & $\begin{array}{l}\text { Child and youth } \\
\text { wellbeing index } \\
2007\end{array}$ & $\begin{array}{l}\text { KIDS COUNT } \\
2018\end{array}$ & $\begin{array}{l}\text { KIDS COUNT } \\
\text { Change in rank } \\
1990-2018 \\
\text { (2018 rank) }\end{array}$ & $\begin{array}{l}\text { End of childhood } \\
\text { index } \\
2018\end{array}$ & $\begin{array}{l}\text { \% of families } \\
\text { receiving TANF } \\
\text { that meet } \\
\text { eligibility criteria }\end{array}$ & $\begin{array}{l}\% 3 \text { and 4-year } \\
\text { olds enrolled in } \\
\text { preschool }\end{array}$ & $\begin{array}{l}\text { Pre-school state } \\
\text { resources per } \\
\text { child }\end{array}$ \\
\hline Top 5 & $\begin{array}{l}\text { New Jersey } \\
\text { Massachusetts } \\
\text { New Hampshire } \\
\text { Utah } \\
\text { Connecticut }\end{array}$ & $\begin{array}{l}\text { New Hampshire } \\
\text { Massachusetts } \\
\text { New Jersey } \\
\text { Minnesota } \\
\text { lowa }\end{array}$ & $\begin{array}{l}\text { Illinois (22) } \\
\text { Virginia (10) } \\
\text { Tennessee (46) } \\
\text { Georgia (39) } \\
\text { Idaho (21) } \\
\text { New Jersey (3) }\end{array}$ & $\begin{array}{l}\text { New Jersey } \\
\text { Massachusetts } \\
\text { Vermont } \\
\text { New Hampshire } \\
\text { Connecticut }\end{array}$ & $\begin{array}{l}\text { California } \\
\text { Minnesota } \\
\text { Vermont } \\
\text { New York } \\
\text { Hawaii }\end{array}$ & $\begin{array}{l}\text { District of } \\
\text { Columbia } \\
\text { Florida } \\
\text { Vermont } \\
\text { Oklahoma } \\
\text { Wisconsin }\end{array}$ & $\begin{array}{l}\text { District of } \\
\text { Columbia } \\
\text { New Jersey } \\
\text { Oregon } \\
\text { Washington } \\
\text { Connecticut }\end{array}$ \\
\hline Bottom 5 & $\begin{array}{l}\text { Nevada } \\
\text { Arkansas } \\
\text { Louisiana } \\
\text { Mississippi } \\
\text { New Mexico }\end{array}$ & $\begin{array}{l}\text { Alaska } \\
\text { Nevada } \\
\text { Mississippi } \\
\text { Louisiana } \\
\text { New Mexico }\end{array}$ & $\begin{array}{l}\text { Oregon (30) } \\
\text { New Mexico (50) } \\
\text { Rhode Island (19) } \\
\text { Nevada (47) } \\
\text { Alaska (46) }\end{array}$ & $\begin{array}{l}\text { George } \\
\text { New Mexico } \\
\text { Oklahoma } \\
\text { Mississippi } \\
\text { Louisiana }\end{array}$ & $\begin{array}{l}\text { Wyoming } \\
\text { Arkansas } \\
\text { Georgia } \\
\text { Texas } \\
\text { Louisiana }\end{array}$ & $\begin{array}{l}\text { Idaho } \\
\text { Montana } \\
\text { New Hampshire } \\
\text { North Dakota } \\
\text { Utah } \\
\text { Wyoming }\end{array}$ & $\begin{array}{l}\text { Idaho } \\
\text { Montana } \\
\text { New Hampshire } \\
\text { North Dakota } \\
\text { Utah } \\
\text { Wyoming }\end{array}$ \\
\hline
\end{tabular}

O'Hare et al., 2013; Floyd, Pavetti and Schott, 2017; Annie E Casey Foundation, 2018b; Save the Children, 2018a; The National Institute for Early Education Research, 2018, Note: where there are more than five states listed this is due to ties. 
Table A4: Top and bottom states for federal and state spending on child welfare, spending per child in the general population 2014 and Change 2004- 2014

\begin{tabular}{|c|c|c|c|c|}
\hline & Federal spending $^{1}$ & State spending & Overall spending & Difference 2004-2014 \\
\hline Top 5 & $\begin{array}{l}\text { District of Columbia } \\
\text { Vermont } \\
\text { Michigan } \\
\text { Rohde Island } \\
\text { West Virginia }\end{array}$ & $\begin{array}{l}\text { District of Columbia } \\
\text { Rohde Island } \\
\text { Connecticut } \\
\text { Pennsylvania } \\
\text { Alaska }\end{array}$ & $\begin{array}{l}\text { District of Columbia } \\
\text { Connecticut } \\
\text { Alaska } \\
\text { Pennsylvania } \\
\text { Massachusetts }\end{array}$ & $\begin{array}{l}\text { Oregon }(83 \%) \\
\text { Utah }(76 \%) \\
\text { Virginia }(71 \%) \\
\text { New Jersey }(64 \%) \\
\text { Nebraska }(40 \%)\end{array}$ \\
\hline Bottom 5 & $\begin{array}{l}\text { Colorado } \\
\text { Texas } \\
\text { Idaho } \\
\text { Utah } \\
\text { Delaware } \\
\text { Puerto Rico }\end{array}$ & $\begin{array}{l}\text { Arkansas } \\
\text { New Mexico } \\
\text { New York } \\
\text { West Virginia } \\
\text { Idaho }\end{array}$ & $\begin{array}{l}\text { New Mexico } \\
\text { Arkansas } \\
\text { Oregon } \\
\text { Texas } \\
\text { Idaho }\end{array}$ & $\begin{array}{l}\text { District of Columbia (- } \\
26 \%) \\
\text { Minnesota }(-26 \%) \\
\text { Wyoming }(-27 \%) \\
\text { lowa }(-30 \%) \\
\text { New York }(-31 \%)\end{array}$ \\
\hline
\end{tabular}

Connelly and Rosinsky, 2018a. Note: ${ }^{1}$ six states listed for bottom 5 due to a tie 


\section{Fostering policy support for child and family wellbeing - Learning from international experience}

Across different countries globally, societies value and see a duty to ensure children's health and wellbeing, not only as response to their rights and vulnerability, but also as an investment in their capabilities. Child health and wellbeing is located within the health and wellbeing of their families, affected by their community and material environments and by the services and interventions they access. All this is influenced by social values, shared norms, laws and policy.

Policy recognition of and support for family and child health and wellbeing differs across countries and there is concern to raise support for it in the USA.This raises a question of how changes in policy norms and recognition have been achieved in countries, and what transferable learning there is for the USA.

The evidence being gathered in the project aims to address this question. 